\title{
Functional Traits in Lichen Ecology: A Review of Challenge and Opportunity
}

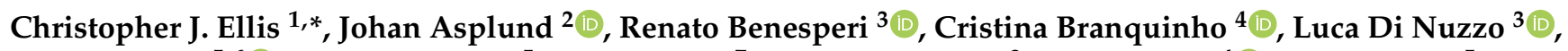 \\ Pilar Hurtado ${ }^{5,6}{ }^{\oplus}$, Isabel Martínez ${ }^{5}$, Paula Matos ${ }^{7}$, Juri Nascimbene ${ }^{8}$, Pedro Pinho ${ }^{4} \mathbb{D}^{\circ}$, María Prieto ${ }^{5}$, \\ Bernardo Rocha ${ }^{4}{ }^{\circ}$, Clara Rodríguez-Arribas ${ }^{5}$, Holger Thüs ${ }^{9}\left(\right.$ and Paolo Giordani ${ }^{10}$
}

check for

updates

Citation: Ellis, C.J.; Asplund, J.; Benesperi, R.; Branquinho, C.; Di Nuzzo, L.; Hurtado, P.; Martínez, I.; Matos, P.; Nascimbene, J.; Pinho, P.; et al. Functional Traits in Lichen Ecology: A Review of Challenge and Opportunity. Microorganisms 2021, 9, 766. https://doi.org/10.3390/ microorganisms 9040766

Academic Editor: Colin R. Jackson

Received: 1 March 2021

Accepted: 31 March 2021

Published: 6 April 2021

Publisher's Note: MDPI stays neutral with regard to jurisdictional claims in published maps and institutional affiliations.

Copyright: (C) 2021 by the authors. Licensee MDPI, Basel, Switzerland. This article is an open access article distributed under the terms and conditions of the Creative Commons Attribution (CC BY) license (https:/ / creativecommons.org/licenses/by/ $4.0 /)$.
1 Royal Botanic Garden Edinburgh, 20A Inverleith Row, Edinburgh EH3 5LR, UK

2 Faculty of Environmental Sciences and Natural Resource Management, Norwegian University of Life Sciences, 5003 NO-1432 Ås, Norway; johan.asplund@nmbu.no

3 Dipartimento di Biologia, Università di Firenze, Via la Pira, 450121 Florence, Italy; renato.benesperi@unifi.it (R.B.); luca.dinuzzo@unifi.it (L.D.N.)

4 Centre for Ecology, Evolution and Environmental Changes (cE3c), Faculdade de Ciências, Universidade de Lisboa, Campo Grande, C2, Piso 5, 1749-016 Lisboa, Portugal; cmbranquinho@fc.ul.pt (C.B.); paplopes@fc.ul.pt (P.P.); brerocha@fc.ul.pt (B.R.)

5 Área de Biodiversidad y Conservación, Departamento de Biología, Geología, Física y Química Inorgánica, ESCET, Universidad Rey Juan Carlos, 28933 Móstoles, Spain; pilar.hurtado@urjc.es (P.H.); isabel.martinez@urjc.es (I.M.); maría.prieto@urjc.es (M.P.); clara.rodriguez@urjc.es (C.R.-A.)

6 Departamento de Biología (Botánica), Universidad Autónoma de Madrid, c/Darwin, 2, 28049 Madrid, Spain

7 MARE-Marine and Environmental Sciences Centre, Faculdade de Ciências, Universidade de Lisboa, Campo Grande, 1749-016 Lisboa, Portugal; psmatos@fc.ul.pt

8 Department of Biological, Geological and Environmental Sciences, Alma Mater Studiorum, University of Bologna, I-40126 Bologna, Italy; juri.nascimbene@unibo.it

9 Botany Department, State Museum of Natural History Stuttgart, Rosenstein 1, 70191 Stuttgart, Germany; holger.thues@smns-bw.de

10 DIFAR, University of Genova, Viale Cembrano, 4, I-16148 Genova, Italy; giordani@difar.unige.it

* Correspondence: c.ellis@rbge.org.uk; Tel.: +44-(0)131-248-2993

Abstract: Community ecology has experienced a major transition, from a focus on patterns in taxonomic composition, to revealing the processes underlying community assembly through the analysis of species functional traits. The power of the functional trait approach is its generality, predictive capacity such as with respect to environmental change, and, through linkage of response and effect traits, the synthesis of community assembly with ecosystem function and services. Lichens are a potentially rich source of information about how traits govern community structure and function, thereby creating opportunity to better integrate lichens into 'mainstream' ecological studies, while lichen ecology and conservation can also benefit from using the trait approach as an investigative tool. This paper brings together a range of author perspectives to review the use of traits in lichenology, particularly with respect to European ecosystems from the Mediterranean to the Arctic-Alpine. It emphasizes the types of traits that lichenologists have used in their studies, both response and effect, the bundling of traits towards the evolution of life-history strategies, and the critical importance of scale (both spatial and temporal) in functional trait ecology.

Keywords: ecosystem services; effect traits; functional ecology; lichenised-fungi; life-history strategy; response traits; scale; spatial; temporal

\section{Introduction}

Focusing on groups such as vascular plants and freshwater invertebrates [1,2] the ecological approach to explaining biodiversity has undergone a major transition from the specific, taxonomically descriptive and pattern-based [3-5], towards the dynamically processbased, generalisable and predictive [6-8]. The logic behind this transition is the identification of functional traits (sensu [9]) as the measurable attributes of an organism's phenotype 
that account for its ecological response to one or more biotic or abiotic, spatial or temporal gradients constituting the environment. Accordingly, the distributions, occurrence and abundances of lichen species, and their contributions to community structure, are explained by identifying non-random patterns of functional traits in space and time, allowing the subsequent inference of assembly rules $[10,11]$.

Lichens have an important but still unfulfilled potential in completing this conceptual transition from pattern to process. For example, as the cohabitant combination of fungi and algae (and/or cyanobacteria) they lie within the realm of 'microorganisms' but are often of a size and longevity that is suited to practical investigation, and so, being amenable to standard ecological tools, they can open a window on species response and community assembly relevant to a wider spectrum of the Earth's biodiversity. They are also the outcome of a complex evolutionary process involving the different symbiotic partners, and leading to a diversity of phenotypes that reflect, to varying degrees, adaptive radiation or convergent evolution, so providing the rich multivariate framework required to explore linkages between ecological fitness, environmental gradients and ecosystem function. Applying a trait-based approach to lichens has important practical benefits in conservation too; for example, it is the difference between a taxonomic list such as for lichen indicators observed to associate with ecological continuity [12-15], and understanding - with its increased confidence-the features of lichen biology that are mechanistically linked to old-growth conditions because of interactions with environmental constraints [16-18].

If functional traits can help us explain and understand the species response to the environment (see Types of Traits, below), they can also, by extension, invoke consequences for ecosystem processes (see Effect Traits, below). The multifaceted power of this functional trait approach, as applied to lichens, is explored in this review. There are three key points that we want to emphasise:

- First, the trait-based approach is integrative, since traits can be explored with respect to community composition and richness, explaining the response of species to the environment, but also the effect that species have within ecosystems, bridging therefore between the classic dichotomy of 'Grinnelian' and 'Eltonian' niche models (see Effect Traits, below).

- Second, it is an approach that links evolutionary biology-the adaptation of the phenotype-with ecology because it focuses on phenotypic attributes that confer fitness differences across environmental space (see Trait Combinations and Interactions, below); these are the outcome of both natural selection and stochastic processes that can explain species distributions, occurrence or abundance, and community structure.

- Third, it is scalable, since traits can be linked to acclimation if they are labile, explaining community composition and richness with respect to intraspecific trait variation, or explaining interspecific compositional turnover where environmental change (spatial or temporal) causes the declining and increasing fitness of species at the boundaries of their trait differences (see Spatial-Temporal Scales, below).

As well as bringing these points together, trait-based approaches may also offer a route through problematic application of lichen systematics to lichen ecology, in which taxonomic concepts may become difficult to apply in practice, as exemplified by a lack of discernible field characters among known species [19-21]. A focus on traits may thus avoid lichens becoming an increasingly narrow specialism within ecology, offering instead a practical route towards integration if a spectrum of functional traits can be identified and applied by non-specialist ecologists. Consequently, trait-based approaches are arguably more powerful, despite being more user-friendly in application [22]. Similarly, while ecological conclusions may be difficult to generalise if drawn from the analysis of species names, given differences in regional species pools that reflect independent evolutionary or biogeographic histories, the use of traits provides opportunity for recognising general ecological rules that govern the way in which communities are assembled, despite species pool differences.

To date, the application of trait-based research to understanding lichen distributions, occurrence or abundances, and/or lichen community structure, has been demonstrably 
effective and this is highlighted through our selection of examples below. Nevertheless, the research groups that have been using trait-based approaches lack a common methodological approach; contrasts include the nomenclature applied to classification of different traits, through to differences in the observed relationship of traits to environment response and ecosystem function. There is still much to discover. Although certain traits are now embedded and routinely used in explaining lichen response, such as the physiological difference between green-algal chlorolichens and cyanolichens $[23,24]$, recent studies also show that, within these categories, there are relevant physiological and functional differences that can more finely resolve the lichen response [25]. There is emerging synthesis around other potentially generalisable traits, especially the lichen response explained by links between phenotype and thallus hydration [26], although again key challenges often remain, including the way in which structurally different phenotypes can converge on the same hydrological response [27]. There are methodological questions to be solved about how this convergence in response is recognised and dealt with analytically.

Recognising both the significant opportunity provided by functional trait studies, and the challenges involved, and without wanting to provide overly prescriptive answers, this paper provides a review of trait-based research in lichen ecology, pointing to a series of recommendations that can move the field forwards. It is drawn from the experience of multiple authors, particularly with respect to European ecosystems from the Mediterranean to the Arctic-Alpine. It emphasises the types of traits that lichenologists have used in their studies, both response and effect, the bundling of traits towards life-history strategies, and the critical importance of scale (both spatial and temporal) in functional trait ecology.

\section{Types of Traits}

Functional traits can be considered in two ways. First, they are the phenotypic attributes that explain the ecological response of a species to one or more biotic or abiotic, spatial or temporal gradients constituting the environment. As stated above, these response traits [28] will control fitness differences across environmental gradients (rates of establishment, survival, reproduction), thus affecting lichen species distributions, occurrence or abundances, and cumulatively across species, community structure. If well characterised, these traits can subsequently provide proxy information on their environmental controls, being useful to monitor environmental change in space and time, including changes that may be more difficult to study by other means (such as for air pollution).

Second, functional traits may describe the effect of a species on ecosystem processes. These effect traits [28] are focused on how a shift in lichen species distributions, occurrence or abundances, and/or community structure, can have consequences for ecosystem functioning, such as lichen nitrogen fixation relevant to terrestrial biogeochemistry, through contribution to nutrient cycling [29-31]. These response and effect categories are not mutually exclusive (Figure 1), and some traits reflect both response and effect simultaneously; accordingly, response and effect traits may, but do not necessarily, overlap. 


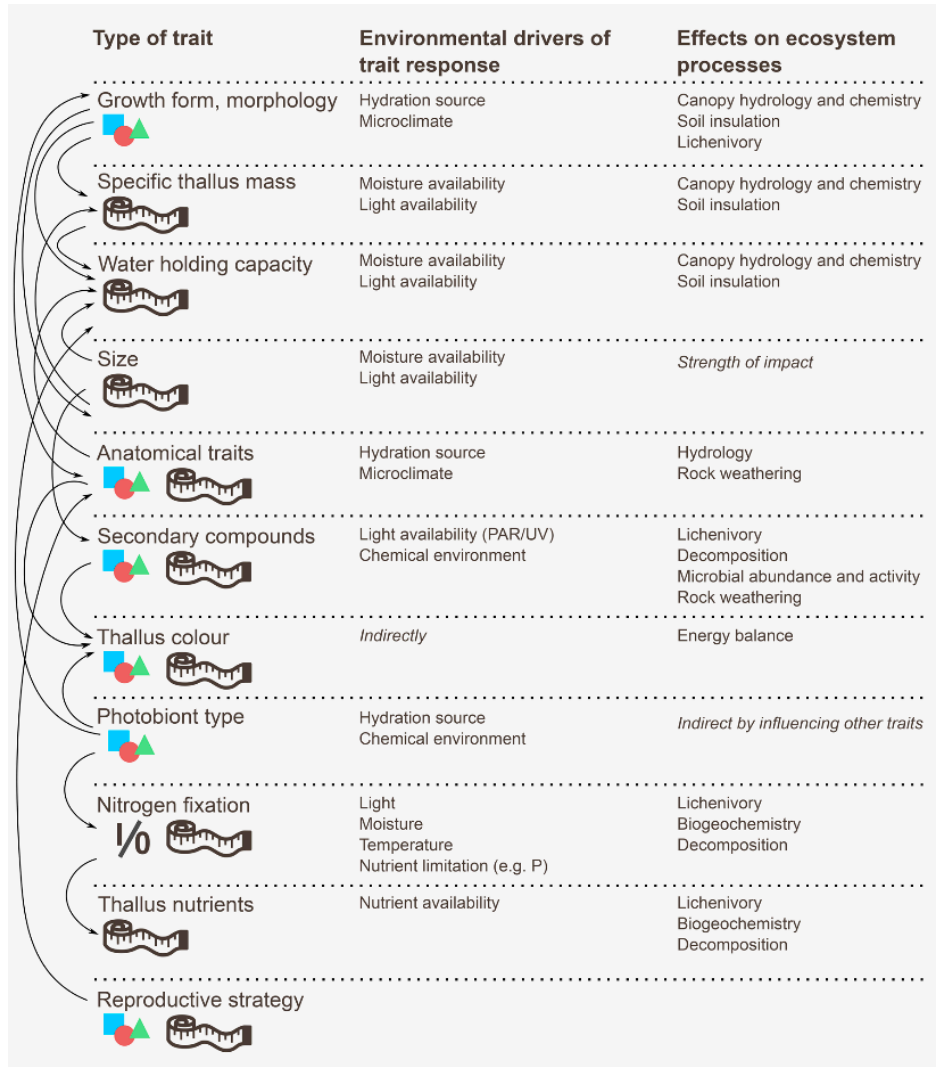

Figure 1. Schematic to show contrasting types of traits that might yield qualitative (shapes) or quantitative (measuring tape) data, and their potential relationship to environmental drivers controlling a species/community response, and/or the effect on ecosystem processes. Arrows show an a priori understanding of linkages between traits (e.g., photobiont type also affects water holding capacity). Note that thallus colour is indirectly related to the environment through associated traits such as photobiont type or secondary compounds. Additionally, that reproductive strategy associates with lichen anatomical traits but is separated out because of its link through to demographic processes that also affect community composition.

\subsection{Response Traits}

In principle, the 'trait space' that lichens might occupy is highly dimensional, since it can combine a wide array of different phenotypic attributes that are measured to varying degrees of precision [32,33]. Key foci in the search for lichen functional traits have included gross thallus morphology and anatomy, the identity of photobionts, attributes linked to hydration and physiology such as surface hydrophobicity or water holding capacity, reproductive mode, and thallus chemistry as nutrient status, secondary metabolites or tissue $\mathrm{pH}$, etc. [32,33]. The search for traits has been related to natural constraints such as drought [34], or anthropogenic drivers such as air pollution [35,36]. The terminology used to organise and think about traits (Table 1) has encompassed the difference between traits that are easier or harder to measure (soft versus hard traits), those drawn from primary data or bibliographic, whether they are quantitative or qualitative, whether they are directly related to physiological response, being proximal, or proxies for response, being distal or compound traits. In providing our introduction to response traits, we here explore some of the different ways in which lichen traits have been organised into the ecologist's toolkit. 
Table 1. A glossary of terminology used to classify trait-based approaches.

\begin{tabular}{|c|c|}
\hline Trait Classification & Explanation \\
\hline Response trait & $\begin{array}{l}\text { A phenotypic attribute that links to fitness differences (rates of } \\
\text { establishment, survival, reproduction), affecting the lichen response } \\
\text { to the environment }\end{array}$ \\
\hline Effect trait & $\begin{array}{l}\text { A phenotypic attribute that affects the lichen role in the ecosystem, } \\
\text { and ecosystem functioning and services }\end{array}$ \\
\hline Soft trait & $\begin{array}{l}\text { An easily measured (often categorical) trait; such a trait may } \\
\text { nevertheless be cost effective and provide high explanatory power }\end{array}$ \\
\hline Hard trait & $\begin{array}{c}\text { A hard to measure (often quantitative trait); these terms (soft and } \\
\text { hard) are subjective and used differently across the ecological } \\
\text { literature, e.g., a hard trait may sometimes be considered analogous } \\
\text { to a proximal trait }\end{array}$ \\
\hline Qualitative trait & A trait measured on a nominal or ordinal scale \\
\hline Quantitative trait & A trait measured on an interval or ratio scale \\
\hline Proximal trait & $\begin{array}{c}\text { Borrowing from the language of niche theory, a trait that captures, } \\
\text { relatively directly, the lichen physiological response or ecosystem } \\
\text { effect }\end{array}$ \\
\hline Distal trait & $\begin{array}{l}\text { In contrast, a summary trait that is less directly related to the lichen } \\
\text { environmental response or ecosystem effect }\end{array}$ \\
\hline Compound trait & $\begin{array}{l}\text { A trait (often distal) that integrates numerous proximal and direct } \\
\text { effects, into a broader summary response to the environment or } \\
\text { ecosystem effect }\end{array}$ \\
\hline $\begin{array}{l}\text { Intraspecific trait } \\
\quad \text { variability }\end{array}$ & $\begin{array}{c}\text { The concept that variability in a trait-plasticity-can be a trait itself, } \\
\text { creating potential for acclimation and affecting-through } \\
\text { response/effect-the lichen niche }\end{array}$ \\
\hline
\end{tabular}

\subsubsection{Explanatory Power or Information Assembly Effort}

Trait-based studies often need to strike a balance between the effort required to measure a given trait and its explanatory power. This links to the flexible but subjective concept of 'hard' and 'soft' traits [32], which are defined by the expenditure (amount of time or money invested, or expertise required) to measure and apply a given trait within a study. In this regard it is important to recognise an ambiguity that brings into question the usefulness of these terms; the measurement of certain traits such as water holding capacity could be relatively easy and not especially time consuming when applied to a foliose lichen (soft trait), while it may, in practice, constitute a hard trait when measured for squamulose species intermingled with soil. There is also a potential confusion of terminology. In the wider plant literature [28] hard traits are considered those which capture a precise function (e.g., nitrogen fixation or litter decomposability), and it is important to be aware of the way in which trait terminology may have been differently applied across ecological domains.

Furthermore, the higher cost involved in measuring certain traits may not always contribute additional information within a hypothesis, compared to insights gained from using more easily obtained trait data. Thus, Hurtado et al. [37-39] found that readily applied categorical traits of epiphytic lichens, such as the growth form and type of photobiont (considered at a high level of systematic classification), were highly relevant in explaining lichen response to macroclimate across a latitudinal gradient in Europe. Surprisingly, traits with a more direct physiological association (e.g., chlorophyll a, water holding capacity, specific thallus mass, tissue $\% \mathrm{~N}$ or $\% \mathrm{C}$ ) were little or not relevant at this scale of analysis. These harder to measure traits may nevertheless be related to smaller-scale environmental variation, with a response signal that is obscured by coarse-grained macroclimatic data. 


\subsubsection{Qualitative versus Quantitative Traits}

Almost all traits can be assessed either as quantitative or qualitative. For example, metabolite profiles could be considered in the form of a presence/absence matrix (relatively low cost), or concentration ranges for each metabolite could be measured and used in a quantitative form (relatively high cost). The use of presence/absence data for metabolite profiles in lichen communities is common practice (e.g., [22,40,41]), but the relative benefits of switching to quantitative metabolite data, with respect to the explanatory power of results, remains to be tested. Similarly, growth forms of lichens represent categories within a continuum. Using a qualitative approach requires an a priori decision over the scale at which differences in growth form are recognised. This is often unacknowledged (such as when growth forms are bibliographic, and drawn from flora accounts), while the number of categories may also differ substantially between studies (e.g., foliose, against foliose broad or narrowly lobed). Quantitative measures reflecting morphological length/width relationships may provide more generalisable data [42], though can be challenging to integrate across species that have a fundamentally different growth form (e.g., fruticose versus crustose species). Studies can often be recognised as aligning themselves along a gradient of trait categorisation that is either more or less finely resolved (cf. [43-45]).

\subsubsection{Bibliographic or Primary Data}

Quantitative traits are often based on primary observations made for a particular lichen population or study area but for qualitative traits it can be common practice to combine field knowledge with information from bibliographic sources, such as original research papers, regional floras (e.g., [46,47]), or databases and data portals, e.g., LIASlight [48], CNALH [49] and ITALIC 6.0 [50]. However, there are often important differences in detail; metabolite profiles in floras and databases are generally coded as presence/absence or in a semiquantitative way (such as describing compounds as trace or accessories versus the main component), but with detailed concentration ranges absent. With the exception of LIASlight, none of the aforementioned resources aims at providing a global representation of lichen traits. This can cause problems because even seemingly simple traits, such as growth form, can be ambiguous when studied over large geographic scales; the prevalence of different types of photosymbiodemes for the same lichen-fungus is the extreme example of this change under different environmental conditions. Reproductive mode (presence of fruiting bodies, in addition or instead of various forms of vegetative propagules) is likewise easily accessible via bibliographic sources, though can also vary substantially within a species across regions. Borrowing from niche theory, one might contrast the fundamental trait (the potential biological range of an attribute), with the realised trait needing to be validated by observations within the study area of interest.

\subsubsection{Proximal or Distal Traits}

Again, borrowing from niche theory [51,52], traits may be considered relatively more proximal if they tend towards a direct link with the lichen physiological response, as may be the case for specific thallus mass $[53,54]$. Or traits may be distal, if they capture response or effects more broadly, such as using growth form. In the latter case, traits may be compound if they summarise responses across different aspects of lichen biology related to multiple environmental variables (see Trait Combinations and Interactions, below). As an analogy, the light response curve of lichens or plants is a very direct physiological response, intermediate might be the specific thallus mass, or for plants the specific leaf area, while compound may be the growth form (fruticose, foliose or crustose), or for plants similar categories such as Raunkiær's life forms (phanerophytes, chamaephytes, hemicryptophytes, etc.). Partitioning the particular relevance of distal/compound traits to any observed trend can be challenging; for example, the lichen growth form may relate to water use strategy and physiology (cf. $[42,53,54])$, though may also have implications for successional processes through competitive species interactions [55], while reproductive mode such as the presence of isidia might affect spatial-temporal response to habitat 
availability through dispersal limitation $[16,56]$ as well as affecting physiology through thallus gas exchange $[57,58]$.

\subsubsection{Variation among Individuals}

Advances in lichen trait studies are exploring the importance of functional trait variability among individuals within a population, as well as among species. The range-or plasticity - of a given trait has consequences for acclimation that may link importantly to the species niche $[59,60]$. For example, since lichens are compound organisms, the specificity of the fungal-photobiont association, and an exploration of this range as a functional trait itself, can reveal acclimation potential through photobiont selectivity to local environmental conditions, creating resilience to environmental change [61,62]. The ecological potential for selectivity is determined by differences in the evolutionary specificity of the lichen fungus, varying from strict specialists to broad generalists (e.g., [63-65]). Generalist species may have advantages across different environments, with more specialist species having narrower geographical distributions and ecological niches [63-65].

The study of lichenometry provides a salient warning about variability in traits below the species level, with respect to growth rates and size. Growth rates and maximum thallus size have long been used in relation to and as a proxy for the time span since major physical disturbance [66,67]. This rests on the assumption that regional calibration of growth rates, within a comparable environment, is possible through analysis of thallus size patterns on substrata with known history. Some knowledge of variability in growth rates and thallus size is important to confirm this assumption. However, new data on cryptic speciation, even with taxa popularly used for lichenometry, such as the Rhizocarpon geographicum aggregate [68], calls into question the standardisation by targeting at a putative species level. Instead, selecting candidate thalli for lichenometry based on homogeneity in relevant traits (growth rates and maximum thallus size) may offer a way out of this problem and in fact may be-albeit unconsciously-already in practice when using morphologybased concepts for taxa such as Rhizocarpon geographicum auct. (e.g., [69]). Furthermore, standardisation of growth rates and thallus size requires that multiple covariables, such as the effects of reproductive stage, substratum type and variation in microclimate also be taken into account $[70,71]$. Having achieved this sufficient level of control, observation of small-scale temperature effects on the freshwater lichen Dermatocarpon rivulorum, in a closely monitored stretch of subalpine watershed, has led Shivarov et al. [72] to propose variability of thallus size and colony extension as a trait for monitoring the effects of climate change.

In summary, recent studies from both a microhabitat scale [73] to biogeographic scale $[37,74]$ have shown that incorporating trait variation for individuals, below the species level ( $\approx$ intraspecific variation), is important when explaining the response of lichen communities not only to microclimates, but also to macroclimates across wide geographic extent. Thus, Hurtado et al. [37], with respect to community structure, and contrary to the general pattern expected for plants, showed that intraspecific variability in functional traits explained the community pattern of epiphytic lichens along a $3000 \mathrm{~km}$ latitudinal gradient in Europe, being a larger effect than species turnover. Intraspecific variability should be taken into account in order to fully understand the effect of environmental change on lichen communities.

\subsection{Effect Traits}

Most trait-based lichen studies have explored response traits; there is a major knowledge gap in our understanding of how these traits may also link to ecosystem function and the delivery of ecosystem services. This requires investigation of the role of effect traits. In many cases response traits may coincide with effect traits, and changes in the trait composition of a community, in response to environmental factors, can ultimately result in a change to how the lichens affect ecosystem function. For this same reason, Lavorel \& Garnier [28] proposed a conceptual framework that linked the response and 
effect traits of plants. They suggested that response traits related to resource availability may be congruent with a direct effect on nutrient cycling, for example. In contrast, traits linked to disturbance, and reflecting demographics, have generally a weaker relationship to ecosystem processes. Whether this framework is broadly applicable to lichens has not been thoroughly tested, despite the fact that lichens play important roles in driving ecosystem function [75] and in supply of ecosystem services [76]. With respect to effect traits, it is noteworthy that conservation policy is increasingly focused away from biodiversity per se, and towards the link between biodiversity and ecosystem services and goods. An improved understanding of lichen effect traits is likely to become a priority therefore, to better understand the role lichens play in ecosystem functioning, and to secure the ecosystem services they provide. This would incorporate the benefits to humans that are derived from lichens, which, when referenced below, are organised using CICES, the Common International Classification of Ecosystem Services [77].

As hypotheses to provoke future research (Figure 2), we here offer the proposal that response traits determining how lichens respond to water availability (e.g., water acquisition and water storage) are also effect traits for how lichens influence the physical properties of the ecosystem, i.e., acting as a regulating service in the water cycle, while also altering the energy balance and microclimate. This represents a regulating ecosystem service. We also suggest that traits determining the lichen response to nutrient availability are important for how lichens influence biogeochemistry. This represents a supporting ecosystem service. As an additional consideration, traits related to growth form and visual aspect may also be critical in the provision of cultural ecosystem services.

\section{PHYSICAL ENVIRONMENT}

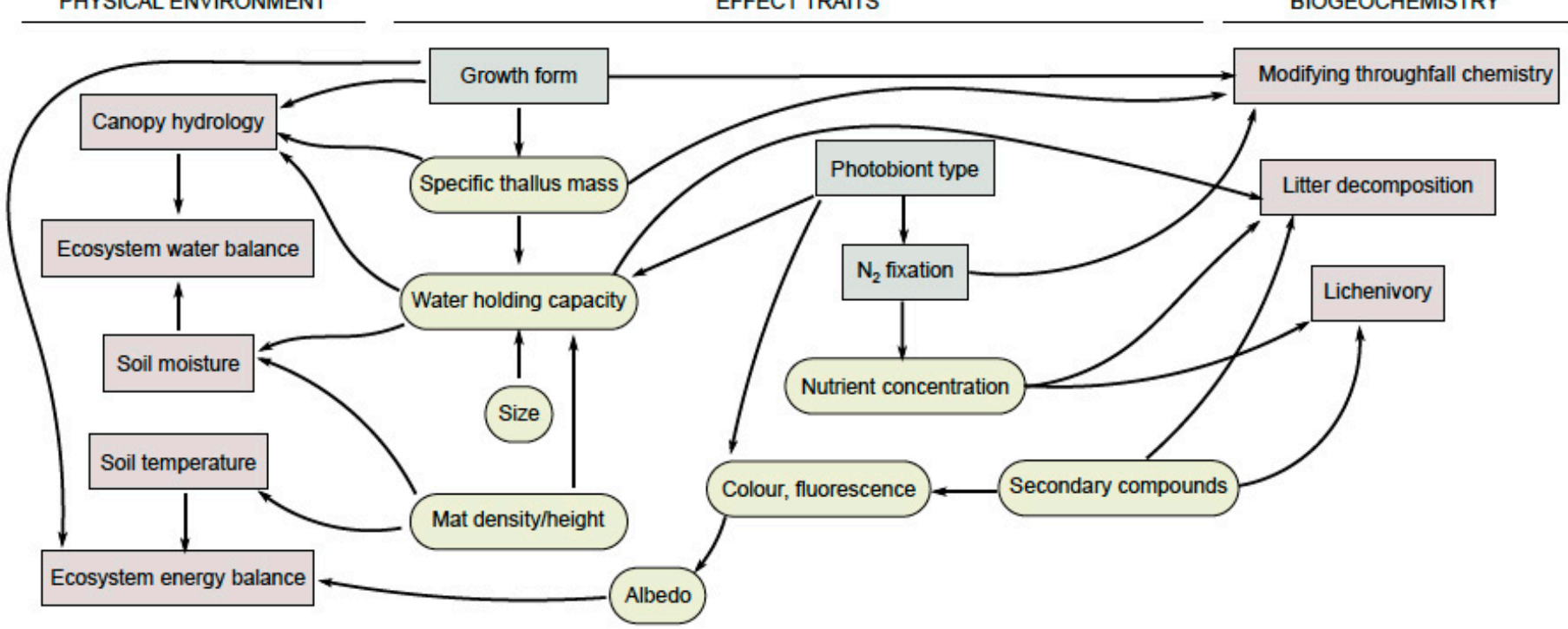

Figure 2. A schematic to suggest how lichen response traits, especially those linked to the key physiological parameter of thallus hydrology (growth form, photobiont type), can also affect the physical environment of energy and water balance as a regulating ecosystem service, while also linking to biogeochemistry as a supporting ecosystem service. As regards the effect traits, boxes represent what are routinely categorical and ellipses continuous measurements.

\subsubsection{Regulating: Water Availability and Energy Balance}

Ground-dwelling (terricolous) lichens directly influence soil microclimates through their physical properties. This influence is strongly linked to thallus morphology, though questions of scale become important (see Spatial-Temporal Scales, below). For example, traits measured at the scale of a population or community, such as 'mat-level' traits of terricolous species, are probably more relevant to regulating services than the variability of individual thalli. For instance, lichen mat density and mat water holding capacity are 
negatively correlated with soil temperature [78,79]. Nystuen et al. [80] also found lower soil temperature under lichens with greater mat thickness, though with these populationor community-level effects unrelated to individually measured attributes. Studies on bryophytes also show that heat transfer through mats is regulated by mat thickness and moisture content [81]. Further, where lichen mats affect the radiation budget by changing albedo, lichen colour (and metabolite profiles, see Types of Traits, above) becomes important, affecting surface temperature [82,83]. Aartsma et al. [84] confirmed that species composition in lichen-rich heath influences albedo and microclimate at the habitat scale.

Morphological attributes can strongly affect thallus water uptake and release, again scaling at the population- or community-level to regulation of the water cycle [85]. Several studies have shown that epiphytic lichens can affect canopy hydrological parameters (see [86]). As such, Pypker et al. [87] showed that epiphytes store 3-5 mm equivalent of rain in an old-growth Douglas-fir forest. Lichens may also reduce stemflow and throughfall, but studies on this remain inconclusive [86]. In fog-driven ecosystems, epiphytic lichens may improve host plant water use through increased fog interception [88]. Most studies regarding the lichen influence on canopy hydrology have not distinguished between species however, making it difficult to directly link these larger-scale processes to individual lichen response traits. Nevertheless, it could be assumed that the key morphological traits related to water uptake and retention [26] are important as effect traits in this context.

Given the evidence to date, it seems a reasonable proposition that the energy balance and ecosystem water economy of lichen dominated habitats emerges from the aggregation and up-scaling of traits that originate with the morphology or structural complexity of individual lichen thalli. Conceptually, lichen morphological studies are now integrating at least two tightly linked continuous response traits, relating strongly to water uptake and release kinetics at a thallus-scale [26,54]—specific thallus mass and water holding capacity — but which are pivotal for how lichens might affect ecosystem hydrology and insulation. As morphology, specific thallus mass and water holding capacity also respond to environmental gradients, e.g., water and light availability $[89,90]$, this is an example of the potentially strong connection between response and effect traits.

\subsubsection{Supporting: Biogeochemistry}

In addition to the effect on hydrology discussed above, lichen epiphytes may alter throughfall and stemflow chemistry and thus play an important role in nutrient cycling [91,92]. More broadly, lichens can significantly affect biogeochemical cycles through surface weathering, nitrogen fixation and by trapping minerals from dry and wet deposition $[92,93]$. The rates at which these processes occur is possibly influenced by lichen traits, although our knowledge of these processes is limited. For instance, lichen rock weathering is certainly influenced by an amalgam of traits [94,95]. Growth form may affect rock weathering, and crustose lichens (especially endolithic examples) often have greater hyphal penetration into rocks than other forms. However, foliose and squamulose species, and especially those with rhizines, may also contribute significantly to rock weathering. Further, thallus expansion and contraction are greatest in gelatinous lichens. Dark-coloured lichens may induce rock weathering by increasing microthermal gradients and thus the number of freeze-thaw cycles [96]. Both qualitative and quantitative variation in metabolites also influence weathering [94]. Ultimately, these trait-determined effects will play a critical role in soil formation and quality, cumulatively over long timescales. The contribution to soil formation may be facilitated by the nitrogen fixation of lichens with a cyanobacterial symbiont [29-31]. As a contrast, the lichen weathering of historic monuments has been viewed as a disbenefit, although some dispute exists as to whether lichen colonisation is offset by thermal insulation and impermeability, thus providing protection of stone [97].

Carbon and nutrients fixed by lichens are ultimately released to the ecosystem through litter decomposition or consumption by various animal groups. There has been a growing interest in how lichen traits drive the rate of these processes (as reviewed by Asplund \& 
Wardle and van Zuijlen et al. $[75,98])$. Lichen palatability is governed by qualitative and quantitative variation in metabolites [33,99-101]. Although thallus nutrient concentration seems to have little effect on grazing by molluscs, for example [33], it plays a role in regulating the abundance of other invertebrates in lichens [45], with potential consequences across food-webs [102]. Geiser et al. [103] developed a model for estimating the loss of forage lichens (e.g., with a role on critical winter forage for ungulates) following nitrogen deposition in US forests, identifying levels of risk to be taken into consideration in land management.

As final considerations, the reduction of cover and diversity in lichen-dominated biocrusts is shown to lower the capacity to sequester atmospheric $\mathrm{CO}_{2}$ [104] while lichens can affect successional processes including the establishment and performance of vascular plants $[80,105]$, and growth form also influences lichen ability to prevent erosion, by retaining soil particles $[106,107]$.

\section{Trait Combinations and Interactions}

Although studies to explain lichen distribution or community structure often consider more than one type of functional trait, many such studies treat these traits as separate individual explanatory effects. This additive approach may be entirely appropriate if the study is focused on a single (or few) strong gradient(s), but there are potential advantages to 'bundling traits', considering their combined and interactive effect, to achieve an integrated evolutionary and ecological perspective. Here, we explore the benefits of bundling traits, highlighting the advantages of this approach, and the challenges of why and how to do it.

\subsection{Why Bundle Traits?}

By bundling traits, we mean considering more explicitly how separately defined functional traits (e.g., specific thallus mass, metabolites, reproductive mode) are interrelated through their evolutionary history, and interact at ecological scales. Lichen species are structurally complex and while the prior cause of a lichen phenotype can be difficult to explain, evolution will nevertheless have operated on the whole phenotype, as natural selection shaped the adaptive capacity of individuals towards effective establishment, survival and reproduction. Individual traits have co-dependent evolutionary histories and shared ecological benefits or constraints, that together determine the lichen response to the environment, and explain lichen distributions, occurrence, abundances and/or community structure. The integration of functional traits, in determining the lichen response to environment, can therefore reflect key linkages between evolutionary history and ecological process, potentially increasing the explanatory power of trait analysis.

\subsection{An Evolutionary Niche Model}

Of critical importance in motivating the analysis of combined and interacting traits is the way in which this trait bundling keeps our studies consistent with models of the evolutionary process. The classic habitat template model of the niche [108,109] describes a process in which the habitat - the amalgam of biotic and abiotic environmental conditions-is a template into which evolution by natural selection shapes the organism's phenotype through adaptation that maximises fitness (establishment, survival, reproduction). This region of fitness is the species niche. Here, in a logic that is internally consistent, the niche links the environment to the evolutionary process of adaptation, explaining the consequent phenotype, and therefore provides a phenotypic explanation of species response to the environment (as measured by ecologists, using functional response traits). This model is consistent with and supported by evidence of convergent evolution, in which unrelated species evolve/acquire similar phenotypes, as they adapt independently to equivalent environments. In a very broad sense, the moisture-harvesting morphology of certain pendulous lichens such as Usnea longissima or $U$. dasopoga appears remarkably similar to that of unrelated taxa such as Tillandsia usneoides (Spanish Moss), while the waterretaining hypothallus of lichens such as Pectenia spp. [110] is similar to the root velamen 
radicum of epiphytic orchids [111,112]; these may be cases of homoplasious adaption to the water-limited epiphytic habitat. However, among unrelated lichen-fungi there has also been striking convergent evolution [113] including in morphology and reproductive structures [114-116]. Furthermore, because we are dealing with the evolution of a composite organism, shared photobiont specificity might also be considered as a functional trait that is potentially convergent across unrelated taxa [117], with these symbiotic relationships recently being extended to consideration of the entire microbiome [118].

How might the habitat template model benefit an understand of lichen distributions or community structure? Since the habitat presents the complexity of environmental conditions into which the whole phenotype has evolved and adapted, one should expect multiple functional response traits to have coevolved (and co-occur) in a way that reflects their combined adaptive value. In other words, the model of an 'environmental filter' does not operate as effectively on single traits, but rather on organisms that are constructed of multiple traits, the combination of which dictate species performance. This explanation becomes increasingly important as the environmental parameters investigated by the ecologist become multivariate, and the functional traits required to understand responses become multidimensional. For example, there are broadly different occurrence/abundance patterns for cyanolichens and chlorolichens in relation to the distribution of moisture [119-121], explained by the widely cited difference in the cyanolichen requirement for liquid water in photosynthesis, compared to an ability to recover photosynthetic activity through uptake of water vapour for chlorolichens $[23,24,122]$. However, a spatial environmental gradient in moisture is likely to covary with the light regime; open dry habitats compared to shady moist habitats. Consequently-alongside and potentially interacting with the photobiontthere will be relevant differences in lichen species response to photosynthetically active photon flux density (PPFD) [123] or colour pigmented photoprotective mechanisms [124] that start to form a bundled set of traits. Extending the role of the phenotype further, and beyond the physical environment (moisture or light), there are biotic interactions also to be considered. Lichens with cyanobacteria tend to have relatively high specific thallus mass (STM), and higher water holding capacity per unit STM $[42,90]$, which facilitates time spent hydrated and physiologically active, but which may also link to biological interactions and their competitive ability in overtopping competitors for space [55]. Furthermore, the occurrence or abundance of lichens contributing to a chronosequence of community structure can be partly explained by a species' reproductive mode and dispersal regime $[125,126]$, while reproductive mode facilitating early or late colonisation may associate with an investment in longevity such as through the synthesis of metabolites [127]. As this consideration of bundled traits starts to become richer and potentially more complex, life-history strategies emerge as a means of summarising multivariate functional response traits through reference to evolutionary trade-offs.

\subsection{Life-History Strategies}

Overall, the bundling of traits described above, as relevant to a spatial-temporal response, resonates to some degree with the $r-K$ concept of life-history strategies $[128,129]$, describing a trade-off between short generation times and rapid colonisation, and longergeneration times and competitive ability. Similarly, an apparently parallel response to gradients of light/moisture and the pollution regime $[130,131]$, could be viewed as partially analogous to the stress-gradient derived from the C-S-R model of life-history strategies $[132,133]$. It is tempting therefore to reduce the high-dimensional space occupied by combinations of interacting traits into fewer life-history strategies that reflect key trade-offs in environmental adaptation (cf. $[108,109,129,132])$. However, this poses some additional challenge. First, the primary models of life-history strategy have been developed with taxonomic bias towards, for example, animals and plants, and their relevance to a group with as complex an evolutionary history as lichens [134], remains to be fully tested (though see, for example: [135]). Second, the life-history strategy approach is so general that it is arguably too blunt a tool, and the flexible search for specific trait combinations that are 
relevant to a particular question, allowing for a specific context of environmental gradients and scale, may be more insightful (cf. $[36,136])$. This flexibility poses its own challenges, however.

\subsection{Conceptual Advances and Challenges}

Consistent with our argument that functional response traits may be strongly linked through their shared evolutionary history, methods in trait analysis also clearly advocate that this non-independence of traits, shared among phylogenetically related species, needs to be accounted for (though see [137]). For example:

- One needs to take account of phylogenetic relationships, based on the assumption that closely related species share underlying similarities (they are not evolutionarily independent), with this non-independence incorporated into tests of trait-environment relationships to avoid statistical error, i.e., erroneously high degrees of freedom, type I error [138];

- One might also include phylogenetic relationships in order to account for similarities among species that exist because of niche conservatism, but that are unmeasured by the traits being used; effectively using phylogenetic clustering as a proxy for unmeasured functional traits, and prompting a search for new functional traits [139]; - One might further include phylogenetic relationships to strengthen understanding of community assembly, as over- and under-dispersed phylogenetic clustering $[140,141]$, though interpreted in the context of macroevolutionary processes such as convergent evolution or adaptive radiation.

This integration of phylogeny, traits and community structure can now be implemented by various methods, e.g., phylogenetic generalised least-squares linear models (PGLS) and phylogenetic generalised linear mixed models (PGLMM) [142,143], and these have been applied within recent lichen studies that innovatively integrate phylogeny and trait analyses $[38,144]$.

An additional challenge is posed by traits that are dissimilar in appearance, but which are functionally similar, considering the difficulty of recognising and accommodating these, such as the role of (pseudo)cyphellae (e.g., Pseudocyphellaria, Sticta) or pores (e.g., Melanohalea) in thallus hydration and gas exchange. This could be extended to traits that have several, but quite contrasting functions, such as the relevance of diaspores (isidia/soredia) to both dispersal and gas exchange [57,58]. Furthermore, it is possible that traits interact in such a way that the role and relevance of a trait could shift depending on the environmental context. A reasonable example could be the preferential occurrence of cyanolichens in relatively drier environments (skewed away from their moisture niche optima), if, for example, these have lower throughfall nitrogen loading than wetter environments, from which cyanolichens are excluded by a physiological sensitivity to air pollution.

\section{Spatial-Temporal Scales}

A lesson emerging from our review is that the initial trait choice for ecological investigation needs to consciously address the scale of biological organisation, such as the trait variability within a single individual, variability among populations within a species, among species and among communities. Depending on the research question, traits will typically be assessed within a certain part of this spectrum, by carefully matching the scale of biological organisation with the environmental scale of interest. This matching is one of the key challenges of trait analysis [145] since traits may respond to environmental drivers across different scales. For example, climate variables might influence lichen species through a functional trait response that has signatures at a regional scale, while the same signatures may also be found at a nested microhabitat scale, as species respond to locally suitable microclimates that can be outliers within a sub-optimal climatic regime, as has been shown for cyanolichens and cyanolichen communities [146,147]. 
Research design must therefore consider how the environment might influence across scales to affect lichen distributions, while also accounting for scales of biological organisation that inform the trait analysis. As a starting point, one might ask, what are the environmental factors that, for a given spatial and temporal context (being scale-dependent), are limiting the performance of lichens, their establishment, survival, reproduction, as revealed through the concurrent analysis of traits appropriate to that scale? We reviewed the recent literature to understand how authors might have approached temporal and spatial scale, while also considering the scale of biological organisation and the environmental factor of interest (Figure 3). Although not exhaustive, it is apparent that the greatest number of studies for both response traits (Figure 3a) and effect traits (Figure 3b) have been for individual time-points applied across all spatial scales (from local to global), irrespective of environmental factor; and while community-scale has been the dominant focus for response traits, this is balanced by a similar number of species-scale studies when effect traits are considered.

(a) Response traits
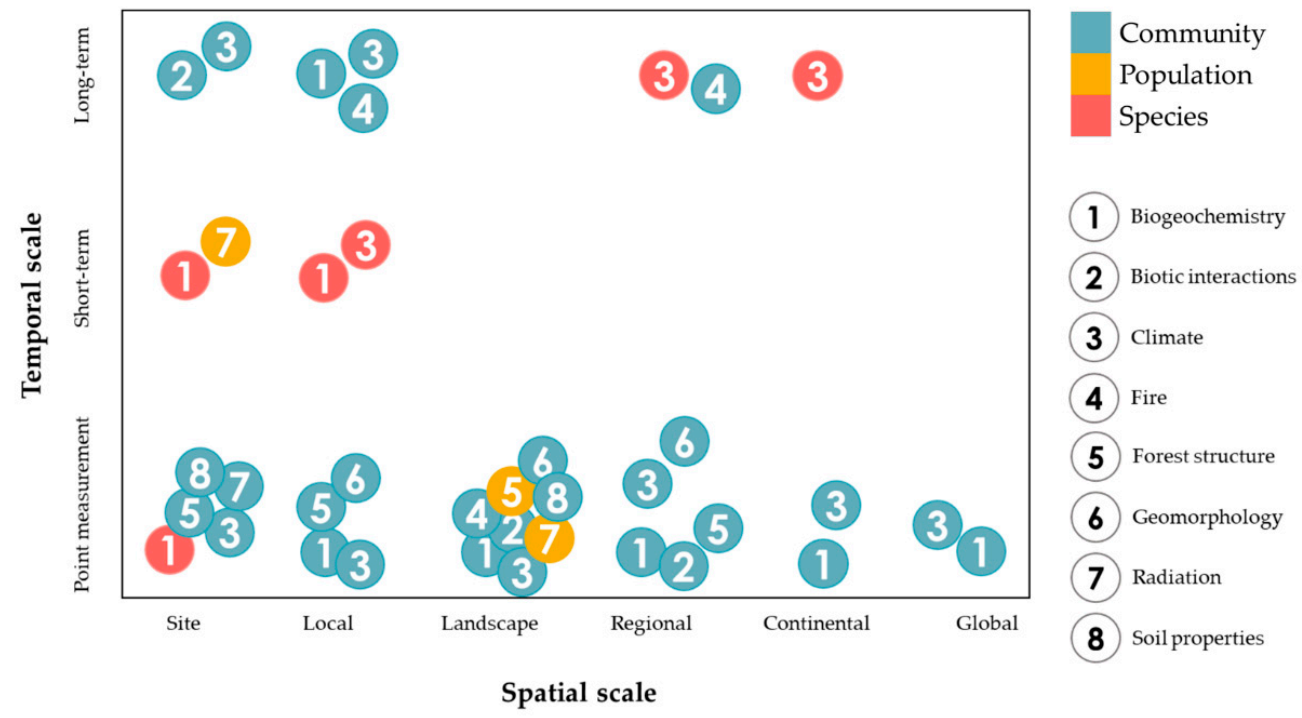

(b) Effect traits

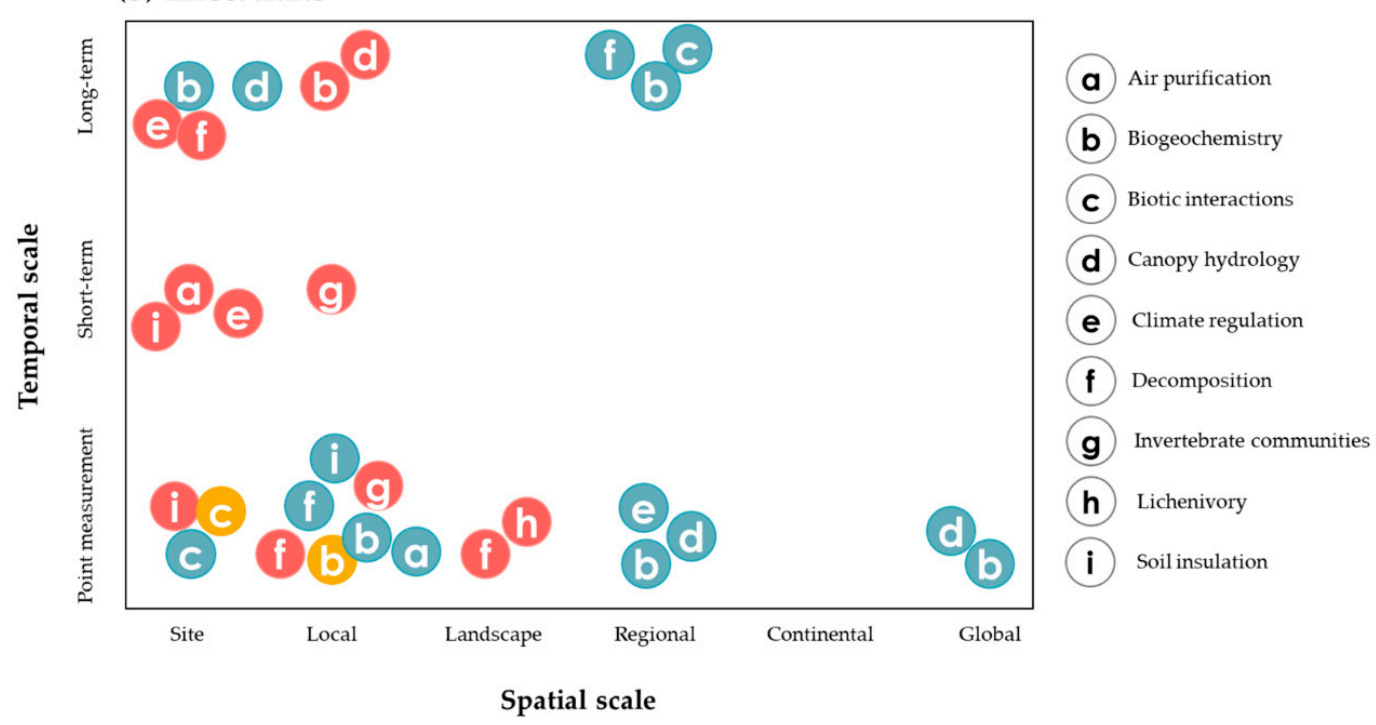

Figure 3. A sample of trait-based lichen studies, comparing the use of temporal and spatial scale (vertical and horizontal axes), when considering the scale of biological organisation (colour) and the environmental factor(s) of interest (numbered) for (a) response traits and (b) effect traits. The plot is supported by the review of studies presented in Supplementary Tables S1 and S2. 
We explore the issue of scale further, by discussing specific examples below.

\subsection{Biological Scale}

The biological scale can be expanded into a hierarchical framework in which structures are defined by part-whole relationships. Entities at higher levels are composed of parts from lower levels. In this classical system, levels of biological organisation include the atomic, molecular, cellular, tissue, organ, organismal, group, population, community, ecosystem, landscape, and biosphere; components that are structured hierarchically in space and time. Higher level abiotic conditions, such as macroclimatic variability and regional biogeochemistry, can impose constraints on lower-level biological processes [148]. However, following the principle of emergent properties, each successive level of biological organisation can acquire attributes that are not simply the sum of observations made in a previous lower level [149]; consequently, it is important to choose traits at a level of biological organisation that reflect responsiveness to the appropriate environmental scale. This choice is not always easy. For example, in understanding the desiccation curves for a single thallus, its anatomy, morphology, and particularly upper surface characteristics such as the presence of a cortex are important [150]. However, when multiple thalli of the same species coexist as a population, then shared morphological complexity can lead to an extended phenotype [151], pointing to the need for a more aggregated, higher-level analysis of traits. As a caveat, other poikilohydric organisms, such as some aquatic bryophytes, including Fontinalis antipyretica, have been wrongly classified as desiccation intolerant based on experiments applied to single shoots [152]. Although the level of relative humidity at which these experiments were performed was realistic, the rate of water loss was unrepresentative of natural conditions, because tests were performed on isolated leaves or shoots. In contrast, under field conditions, this aquatic moss is known to survive summer periods of Mediterranean drought (2-3 months) when it stands out of water owing to decreased river flow [153]. Consequently, in performing the same desiccation experiment though using the entire moss colony, instead of single shoots, the outcome was different, and the moss was classified as being desiccation tolerant in line with field knowledge. Simple features of bryophyte morphology and life form, instead of individual leaf traits, can more effectively capture the ecological adaptation of bryophytes to habitats with different water availability.

Although certain levels of biological organisation may be more relevant to answering a specific research question than others, it is important not to overlook the potential for trait variability at one level of biological organisation to affect responses at different scales of analysis. A study assessing variation of traits related to photosynthetic performance, nutrient cycling and water use in epiphytic lichens across Europe showed that interspecific variation (order and species level contrasts) explained a proportion of lichen response overall [38]. However, when trait variation was analysed at the level of community structure, intraspecific trait variability made a higher contribution than interspecific differences even at this continental scale [37]. In helping to guide researchers through the issue of scale, and with respect to the impact of anthropogenic drivers (such as air pollution and climate change), Branquinho et al. [154] proposed different biological scale measures depending on the intensity of the driver: (i) Ecophysiology-based metrics for low intensity drivers affecting organisms' individual performance; (ii) Trait-based metrics being reserved for medium intensity drivers that differentiate the ecological performance of sensitive compared to tolerant species, causing shifted abundances and resulting in community-level functional properties; and (iii) Taxonomic-based metrics for broader scale impacts which may culminate in species loss [154]. It was proposed that impacts on lichens should be measured, from the highest to the lowest levels of biological organisation, focusing on the initial level of organisation that shows significant variance.

\subsection{Spatial Scale}

It is axiomatic that spatial scale plays a central role in ecological questions and conclusions [148]. The two main characteristics of spatial scale are: (i) Grain, defined as 
the minimum spatial resolution of the data and (ii) Extent, defined as the scope or domain of the data. Spatial scale is a central consideration since it forms a perspective that governs both the observed pattern of diversity and its dominant ecological processes. Especially considering the potential longevity of lichens, which ties them to deep temporal scales (across decades or centuries), their distributions, occurrence or abundances, and community structure, may be the outcome of multiple environmental drivers operating across multiple scales. Since lichens have been widely used as environmental bioindicators, lessons relating to spatial scale can be drawn from the rich canon of work addressing global change.

Traits have been investigated with respect to the larger-scale (macroscale) environment (cf. [39,155,156]; and for ecosystem functioning see [85,93,157]); for example, in relation to climate sensitivity, Matos et al. [34] suggested that photobiont type was particularly sensitive to aridity, highlighting its role in understanding the lichen response to and their potential as indicators of climate change. This macroscale sets the scene for nested and regional effects (mesoscale) such as land-cover classes that might explain differences among lichen functional groups, inferred from their ecological preferences for nutrient availability [158]. Thus, the distance over which nutrient regimes might influence lichen functional groups can depend on land-cover type: (i) 'Annual cultures' had their maximum influence at distances of $600 \mathrm{~m}$; (ii) 'Bare-lands' at $3400 \mathrm{~m}$; (iii) 'Artificial areas' at $1800 \mathrm{~m}$; (iv) 'Ocean', which may account for factors such as salt spray, altitude and humidity, had the largest scale of influence over lichens, ranging from distances of $1800 \mathrm{~m}$ to more than $6600 \mathrm{~m}$ [158]. This nesting of effects within a given broader scale again highlights the importance of considering how lichen response is affected by different environmental variables across scales. To illustrate this point further, at a similar mesoscale, Prieto et al. [144], in an analysis of beech forests in the Iberian Peninsula, found that environmental filtering and local species interactions regulated lichen communities differently under contrasting environmental conditions. Likewise, Hurtado et al. [159] found contrasting factors controlling the functional composition of lichen communities measured at the local scale, for different biogeographic regions, again suggesting that environmental drivers have a cross-scale spatial interaction. These studies also remind us that biodiversity is the outcome of processes operating across locales (across their granularity, for a given extent). Beta diversity patterns for Lobarion communities in Italian forests were significantly determined by factors relating to the forest structure [160], but with the relative importance of the different structural features dependent on the spatial scale of observation.

The microscale is represented by its amalgam of local chemical-physical characteristics such as might be encountered on a tree, or on stonework, representing the fundamental habitat for an epiphytic or an epilithic lichen, respectively. At this smaller scale, several works have reached beyond occurrence/abundance patterns, to investigate demographics, including population structure and species fecundity [161,162]. For example, Rubio-Salcedo et al. [163] showed that tree species was the most important factor in generating different patterns of establishment, revealed through intraspecific variability in traits such as thallus size and reproductive capacity for Lobaria pulmonaria. However, as with nested effects at the regional scale, interactions can play a fundamental role at the microscale, as demonstrated for a study analysing the structure of Lobaria pulmonaria populations in different forest types in Italy [164]. The tree-level probability of occurrence was influenced by the interplay between the forest habitat type and abiotic and biotic factors whose interactive effects varied during the life cycle of the lichen, again revealed through intraspecific trait variability such as for thallus size. Thus, the effect of forest habitat type was significant only for adult thalli while the early life stages were habitat-independent and were strictly associated with tree-level factors. While experimental tests have studied the relationships between water availability and the eco-physiological response of lichens, with size $(\approx$ life stage) as a key trait $[110,161]$, knowledge of the role of intraspecific traits and interactions at the microscale is generally limited (though see [73] for insightful analysis). This is mainly due to the difficulty of assessing, in a cost-effective way, the microhabitat features that 
characterise the microenvironment. In a few studies, microenvironment is quantified; Giordani et al. [156] modelled the occurrence of epilithic lichens in response to light and water availability, to reveal a clear alternation between foliose and fruticose, and crustose growth forms, with decreasing light, suggesting that an excessive availability of water reduced the presence of foliose lichens.

One of the ecologist's key methods for understanding spatial processes is to use the landscape as a natural experiment, and to focus on situations where environmental gradients can be isolated. In a study on north and south slopes of limited topography (300 $\mathrm{m}$ altitude), lichen traits related to water requirements were patterned into contrasting microclimatic conditions (as controlled by topographic contrasts) despite the close spatial distance between sites [165]. On northern slopes, lichen traits reflected higher water availability, explaining a 13\% shift in community composition when compared to southern slopes [165]. There are situations where insights from carefully chosen study systems have been translated to larger scales. The effect of atmospheric pollution on lichens, leading to widely applied critical loads for nitrogen deposition, have been based on local trends in lichen community composition $[166,167]$. Aimed at integrating different functional groups, different scales, and different temporal ranges, Bowker et al. [168] proposed a multi-scale, hierarchical conceptual model that could predict lichen-moss occurrence and composition as a function of climate and soil variables at five spatial scales on the Colorado Plateau.

\subsection{Temporal Scales}

Temporal scale (with its own resolution of grain and extent) may refer not only to the pace of environmental change, but also to the time lag between the driver and the response. In this way, different aspects of the temporal context can appear to be more or less important in explaining lichen distributions, occurrence or abundances, and community structure. The detection of temporal variation may be one of the most demanding considerations in ecological research due to the difficulty in compiling sufficiently long time series that are systematic and can be reliably analysed. Chronosequences provide one popular solution, and several studies have assessed the importance of temporal context on lichen functional traits and the response to disturbance. For example, Giordani et al. [169] analysed the functional richness of epilithic lichen communities in dry grasslands subject to fire, showing that while community function was only slightly altered in relation to the time elapsed, it was reduced considerably as the frequency of fires increased. In the same way, Concostrina-Zubiri et al. $[78,170,171]$ examined the effect of grazing on biological soil crust communities and recovery after livestock exclusion in the semiarid grasslands of Central Mexico as well as for Mediterranean cork-oak woodlands. They found that differences in grazing impact, and time of recovery from grazing, both resulted in slight shifts in species richness [78], but with important changes in species composition and cover which may affect ecosystem function. Additional results indicated that biocrust functional groups could be used as indicators of the disturbance-recovery processes [78]. The authors also noted that changes in functional composition along these gradients influence different ecosystem processes (see Effect Traits, above).

Aside from chronosequence work, direct monitoring data is limited, but has been applied notably in climate change impact studies. Van Herk et al. [172] found evidence that recent change in the lichen flora of the Netherlands was attributable to an increase in temperature. Compositional shifts that had occurred over the last 22 years were considered in relation to species biogeography, to show that arctic-alpine/boreo-montane lichens appeared to be declining, with (sub)tropical lichens increasing. Linking through to traits, Aptroot \& van Herk [173] then showed that lichens responding to climate change in Western Europe, particularly epiphyte species that were increasing in forests, tended to contain Trentepohlia as the photobiont, in addition to having a southern distribution. In another global change study, epiphytic lichen communities were assessed over fifteen years in a semiarid region of Portugal [174], with functional diversity included as one 
of several metrics tested. Compositional changes were shown to be mediated through the response of lichen functional diversity, unrelated to species richness, and principally observed as the sensitivity of photobiont, growth form and size, to the number of days with relative humidity greater than $95 \%$.

\subsection{Interactions Across Scales}

We conclude this section with the emphasis that variables act simultaneously across different spatial and temporal scales to affect lichens. With respect to global change, pointsource responses, such as the presence of nitrophytic lichens in response to cattle grazing, could be relatively local, while climate change-although having local effects-is ultimately a global driver. There may be exceptional cases in which local drivers can lead to global responses, as in the case of radionuclide bioaccumulation [175] following nuclear accidents, while, conversely, large-scale drivers could cause local effects such as the consequences of isolation on individual populations following massive deforestation. Some lichen traits that are currently widely used in ecological studies, such as growth form, photobiont type, reproductive mode and production of metabolites, have been identified as relevant to broad-scale drivers such as macroclimatic conditions, pollution and disturbance gradients, etc. $[34,40,176,177]$. However, additional work is needed to understand the added value of more expensive to measure physiological traits (e.g., chlorophyll a content, water holding capacity, nutrient content and isotopes) and how these might correlate with or emerge from within broader traits, while responding to fine-scale drivers (e.g., microclimatic conditions) or, conversely, being more relevant as effect traits and useful to assess the impact of community structure on ecosystem function and services [39].

Although an explicit identification of the scale (i.e., biological, spatial or temporal) is necessary in analysis of response traits, the inter-linked consequences for ecosystem functioning remains a knowledge gap. There may be interactions between response and effect across scales. These cross-scale interactions have been observed for example by studying the functional over-redundancy and vulnerability of lichen communities in the Mediterranean environment [178]. Functional over-redundancy increased with spatial scale (creating ecosystem resilience), and functional vulnerability decreased with cross-scale interactions; increased warming and climatic extremes caused trait clustering into a small number of resistant (stress-tolerant) functional entities. Trait variation operating across levels of biological organisation may be especially relevant for the ecological dynamics of trophic systems. For instance, variability of lichen traits can mediate ecosystem processes relating to decomposition and nutrient cycling through an effect on invertebrates. In this context, studies have highlighted the between-scale effects of lichen secondary metabolites, and growth forms linked to thallus physiology, affecting invertebrate community composition [45,179-181]. Moreover, changes in invertebrate community composition may then operate as a feedback effect on the dispersal, establishment and survival of some lichen species through endozoochory or exozoochory processes [182-186].

\section{Conclusions and Recommendations}

Our review allows us to identify several key considerations for further work.

First, we highlight the speed of recent developments in trait-based studies. Methodological choices need to reflect a trend towards trait-based studies becoming more integrative, for example coupling traits with phylogeny to merge evolutionary and ecological processes. Although there may not be one correct analytical solution to solve a given hypothesis, it is nevertheless important to be clear about a method choice and its caveats. Consider the problem of trait combination and interactions. At the simplest level, one might use multivariate ordination, such as principal components analysis to summarise phenotypes as the covariation across a set of traits, and to analyse complex phenotypes as ordination axis, though this example would assume a linear correlative relationship in trait variation. This could be generalised through the use of non-linear multivariate methods, such as hierarchical agglomerative clustering or nonmetric multidimensional 
scaling (see $[187,188]$ ), while novel statistical approaches such as multivariate tree boosting $[189,190]$ can handle interactions among multivariate response and predictor variables, though in the latter case limited to considering a small number of interactions at each stage of model building. Methods that allow greater flexibility in relationships among traits (e.g., nonmetric multidimensional scaling), have been combined with a non-linear interpretation of ordination space (e.g., nonparametric multiplicative regression), to understand how complex phenotypes fit into different portions of environmental space [191,192]. Similarly, Fourth Corner and RLQ Analysis [193-195] have been used to assess the relationship between community structure, functional traits and the environment, and extensions are now making it possible to account for phylogenetic signal in these types of approach $[195,196]$. Likewise, advanced statistics such as MCMCglmms make it possible to explore the interaction between environments and functional traits, while using the phylogenetic signal as a random effect.

Second, it is important that statistical methods, no matter how powerful, still draw from the selection of traits that are defensibly functional, with the danger that the addition of spurious-functionally unimportant- traits into multivariate analysis could remain hidden while confounding interpretation. It is therefore important that trait analyses across various scales (Figure 3) remain as supported as possible by evidence from experimental biology. This evidence is rapidly advancing with respect to key traits such as morphology [54,197], photobionts [25,198], reproductive mode [199], etc. Experimental evidence for the functionality of traits, allows them to be confidently included within integrative statistical models that can then more reliably test the value of these traits across the wider environment, and with respect to phylogeny.

Third, conclusions about traits are robust if they stand on multiple pillars of support: (i) They are consistent with field observation, (ii) They align with the results of experimentation, such as traits that are shown to have physiological consequences, and (iii) They show consistency with previously published analytical studies. However, this should not preclude novelty. Many morphological and metabolic characters routinely used in lichen taxonomy are still poorly quantified with regard to their precise functional roles. Few ecological papers include traits such as the presence or density and length of, for example, hairs [200], the types and thickness of cortex and medulla [201], subtypes and density of pseudocyphellae, or thallus texture, e.g., the subgelatinous texture in aquatic and subaquatic lichens [202], width and density of cracks in the thallus, etc. Studies are therefore needed that explore covariation between morpho-anatomical traits (e.g., growth form, size, number of laciniae, surface/volume ratio, cortical characteristic, anatomical structure of the thallus) and quantitative physiological data (e.g., FV/FM, chlorophyll a content, MDA, antioxidant activity, water storage), to better elucidate the interaction of lichens with specific ecological factors such as light, water, salts or herbivore pressure [38,59,200,203-205]. Novel insights could be generated by bringing new technologies to bear on lichen traitbased studies. High-throughput pipelines for the characterisation of lichen metabolites and the resulting reference libraries based on MS/MS spectra are quickly enlarging the resource for identification and quantification of metabolites, but they also indicate that older catalogues and widespread bibliographic references were omitting important metabolites even in seemingly well-known lichens such as Hypogymnia physodes [206]. The potential of neglected metabolite groups to improve our understanding in the functional role of metabolite mixtures has not been fully explored. Furthermore, the focus on metabolite profiling remains mostly on acetone soluble substances. Water soluble metabolites (e.g., mycosporines) could be important traits for otherwise inexplicable ecological performance of lichens that lack the better known and typical 'lichen substances' [207]. These developments need the support of a shared infrastructure to link morpho-anatomical and physiological data for a wide range of lichens from different geographic and climatic regions. Even for morpho-anatomical traits, the current data repositories for lichen-fungi lack direct access to original publications from which the data were aggregated and thus do not yet provide a centralised resource that includes a regional breakdown and comparison of 
trait variation across different geographical areas and scales. This goal could be efficiently achieved by modification of existing resources, or else through the establishment of a new infrastructure.

Fourth, it is established that lichens are involved in some key ecosystem processes though we know less about how these processes are affected by individual traits. We can therefore recommend screening experiments across large numbers of lichens with contrasting traits to understand their ecosystem effects $[33,208]$. Lichens are easy to transplant and it is therefore feasible to manipulate lichen communities. Transplantation studies have been used and should be used to evaluate how traits impact ecosystem functioning such as soil surface energy balance and lichen associated invertebrates across trophic levels [79,102]. Removal experiments with plants have likewise proved to be an efficient avenue in exploring relationships between functional groups and ecosystem processes [209-211]. However, despite lichens being a strong candidate for such experiments, this remains an unexplored opportunity that needs to be developed. Recent plant studies have demonstrated that combined response-effect trait frameworks can be powerful predictors of ecosystem function, with empirical tests having been carried out to evaluate response and effect relationships and roles [212]. However, this response-effect framework has hardly been used in lichens and would represent a considerable analytical development. Although we have addressed regulating and supporting services here, the link between response and effect traits could be widened to provisioning services considering lichen metabolites are also of interest in bioprospecting, with materials useful in cosmetics and pharmacy [213], as well as with respect to cultural services [214].

Supplementary Materials: The following are available online at https:/ / www.mdpi.com/article / 10.3390/microorganisms9040766/s1, Table S1: An overview of studies that have aligned spatial and temporal scales, for different resolutions of biological organisation and the environmental response, Table S2: An overview of studies that have aligned spatial and temporal scales, for different resolutions of biological organisation and the ecosystem process.

Author Contributions: Conceptualisation, C.J.E. and P.G.; Introduction, C.J.E.; Types of Traits, R.B., J.N., M.P., C.R.-A. and H.T.; Effect traits, J.A. and P.P.; Trait Combinations and Interactions, C.J.E., P.M. and B.R.; Spatial-Temporal Scales, C.B., L.D.N., P.G., P.H. and I.M.; Conclusions and Recommendations, all authors; Graphical abstract, P.H. and C.R.-A.; Figures, J.A., L.D.N., P.H. and C.R.-A.; writing — original draft preparation, all authors; writing—review, all authors; editing, C.J.E. and P.H. All authors have read and agreed to the published version of the manuscript.

Funding: This research received no external funding.

Institutional Review Board Statement: Not applicable.

Informed Consent Statement: Not applicable.

Data Availability Statement: No data were used in this study.

Conflicts of Interest: The authors declare no conflict of interest.

\section{References}

1. Menezes, S.; Baird, D.J.; Soares, A.M.V.M. Beyond taxonomy: A review of macroinvertebrate trait-based community descriptors as tools for freshwater biomonitoring. J. Appl. Ecol. 2010, 47, 711-719. [CrossRef]

2. Funk, J.L.; Larson, J.E.; Ames, G.M.; Butterfield, B.J.; Cavender-Bares, J.; Firn, J.; Laughlin, D.C.; Sutton-Grier, A.E.; Williams, L.; Wright, J. Revisiting the Holy Grail: Using plant functional traits to understand ecological processes. Biol. Rev. 2017, 92, 1156-1173. [CrossRef]

3. Tansley, A.G. The classification of vegetation and the concept of development. J. Ecol. 1920, 8, 118-149. [CrossRef]

4. Whittaker, R.H. Vegetation of the Great Smoky Mountains. Ecol. Monogr. 1956, 26, 1-80. [CrossRef]

5. Whittaker, R.H. Vegetation of the Siskiyou Mountains, Oregon and California. Ecol. Monogr. 1960, 30, 279-338. [CrossRef]

6. McGill, B.J.; Enquist, B.J.; Weiher, E.; Westoby, M. Rebuilding community ecology from functional traits. Trends Ecol. Evol. 2006, 21, 178-185. [CrossRef]

7. Cornwell, W.K.; Ackerly, D.D. Community assembly and shifts in plant trait distributions across an environmental gradient in coastal California. Ecol. Monogr. 2009, 79, 109-126. [CrossRef] 
8. Kraft, N.J.B.; Ackerly, D.D. Functional trait and phylogenetic tests of community assembly across spatial scales in an Amazonian forest. Ecol. Monogr. 2010, 80, 401-422. [CrossRef]

9. Violle, C.; Navas, M.-L.; Vile, D.; Kazakou, E.; Fortunel, C.; Hummel, I.; Garnier, E. Let the concept of trait be functional! Oikos 2007, 116, 882-892. [CrossRef]

10. Weiher, E.; Keddy, P.A. Assembly rules, null models, and trait dispersion: New questions from old patterns. Oikos 1995, 74, 159-164. [CrossRef]

11. Weiher, E.; Clarke, G.D.P.; Keddy, P.A. Community assembly rules, morphological dispersion, and the coexistence of plant species. Oikos 1998, 81, 309-322. [CrossRef]

12. Rose, F. The epiphytes of oak. In The British Oak; Morris, M.G., Perring, F.H., Eds.; Classey: London, UK, 1974; pp. $250-273$.

13. Rose, F. Lichenological indicators of age and environmental continuity in woodlands. In Lichenology: Progress and Problems, Proceedings of an International Symposium, Amsterdam, the Netherlands, 6-10 September 1976; Brown, D.H., Hawksworth, D.L., Bailey, R.H., Eds.; Academic Press: Cambridge, MA, USA, 1976; pp. 279-307.

14. Selva, S.B. Lichen diversity and stand continuity in the northern hardwoods and spruce-fir forests of northern New England and western New Brunswick. Bryologist 1994, 97, 424-429. [CrossRef]

15. Coppins, A.M.; Coppins, B.J. Indices of Ecological Continuity for Woodland Epiphytic Lichen Habitats in the British Isles; British Lichen Society: London, UK, 2002.

16. Löbel, S.; Snäll, T.; Rydin, H. Species richness patterns and metapopulation processes - evidence from epiphyte communities in boreo-nemoral forests. Ecography 2006, 29, 169-182. [CrossRef]

17. Johansson, V.; Ranius, T.; Snäll, T. Epiphyte metapopulation dynamics are explained by species traits, connectivity, and patch dynamics. Ecology 2012, 93, 235-241. [CrossRef]

18. Williams, L.; Ellis, C.J. Ecological constraints to 'old-growth' lichen indicators: Niche specialism or dispersal limitation? Fungal Ecol. 2018, 34, 20-27. [CrossRef]

19. Crespo, A.; Lumbsch, H.T. Cryptic species in lichen-forming fungi. IMA Fungus 2010, 1, 167-170. [CrossRef]

20. Nunez-Zapata, J.; Divakar, P.K.; Ruth, D.-P.; Cubas, P.; Hawksworth, D.L.; Crespo, A. Conundrums in species concepts: The discovery of a new cryptic species segregated from Parmelina tiliacea (Ascomycota: Parmeliaceae). Lichenologist 2011, 43, 603-616. [CrossRef]

21. Corsie, E.I.; Harrold, P.; Rebecca, Y. No combination of morphological, ecological or chemical characters can reliably diagnose species in the Parmelia saxatilis aggregate in Scotland. Lichenologist 2019, 51, 107-121. [CrossRef]

22. Benítez, A.; Aragón, G.; González, Y.; Prieto, M. Functional traits of epiphytic lichens in response to forest disturbance and as predictors of total richness and diversity. Ecol. Indic. 2018, 86, 18-26. [CrossRef]

23. Lange, O.L.; Kilian, E.; Ziegler, H. Water vapor uptake and photosynthesis of lichens: Performance differences in species with green and blue-green algae as phycobionts. Oecologia 1986, 71, 104-110. [CrossRef]

24. Lange, O.L.; Büdel, B.; Meyer, A.; Kilian, E. Further evidence that activation of net photosynthesis by dry cyanobacterial lichens requires liquid water. Lichenologist 1993, 25, 175-189. [CrossRef]

25. Phinney, N.H.; Solhaug, K.A.; Gauslaa, Y. Photobiont-dependent humidity threshold for chlorolichen photosystem II activation. Planta 2019, 250, 2023-2031. [CrossRef] [PubMed]

26. Gauslaa, Y. Rain, dew, and humid air as drivers of morphology, function and spatial distribution in epiphytic lichens. Lichenologist 2014, 46, 1-16. [CrossRef]

27. Ure, J.D.; Stanton, D.E. Co-dominant anatomically disparate lichens converge in hydrological functional traits. Bryologist 2019, 122, 463-470. [CrossRef]

28. Lavorel, S.; Garnier, E. Predicting changes in community composition and ecosystem functioning from plant traits: Revisiting the Holy Grail. Funct. Ecol. 2002, 16, 545-556. [CrossRef]

29. Forman, R.T.T. Canopy lichens with blue-green algae: A nitrogen source in a Colombian rain forest. Ecology 1975, 56, 1176-1184. [CrossRef]

30. Crittenden, P.D.; Kershaw, K.A. Discovering the role of lichens in the nitrogen cycle in boreal-arctic ecosystems. Bryologist 1978, 81, 258-267. [CrossRef]

31. Green, T.G.A.; Horstmann, J.; Bonnett, H.; Wilkins, A.; Silvester, W.B. Nitrogen fixation by members of the Stictaceae (Lichenes) of New Zealand. New Phytol. 1980, 84, 339-348. [CrossRef]

32. Cornelissen, J.H.C.; Lang, S.I.; Soudzilovskaia, N.A.; During, H.J. Comparative cryptogam ecology: A review of bryophyte and lichen traits that drive biogeochemistry. Ann. Bot. 2007, 99, 987-1001. [CrossRef]

33. Asplund, J.; Wardle, D.A. The impact of secondary compounds and functional characteristics on lichen palatability and decomposition. J. Ecol. 2013, 101, 689-700. [CrossRef]

34. Matos, P.; Pinho, P.; Aragón, G.; Martínez, I.; Nunes, A.; Soares, A.M.V.M.; Branquinho, C. Lichen traits responding to aridity. J. Ecol. 2015, 103, 451-458. [CrossRef]

35. Matos, P.; Vieira, J.; Rocha, B.; Branquinho, C.; Pinho, P. Modeling the provision of air-quality regulation ecosystem service provided by urban green spaces using lichens as ecological indicators. Sci. Total Environ. 2019, 665, 521-530. [CrossRef] [PubMed]

36. Rocha, B.; Pinho, P.; Branquinho, C.; Boieiro, M.; Matos, P. Bringing the concept of ammonia critical levels into managing cork-oak woodland for conservation. For. Ecol. Manag. 2019, 453, 117566. [CrossRef] 
37. Hurtado, P.; Prieto, M.; Aragón, G.; de Bello, F.; Martínez, I. Intraspecific variability drives functional changes in lichen epiphytic communities across Europe. Ecology 2020, 101, 03017. [CrossRef]

38. Hurtado, P.; Prieto, M.; Martínez-Vilalta, J.; Giordani, P.; Aragón, G.; López-Angulo, J.; Košuthová, A.; Merinero, S.; Díaz-Peña, E.M.; Rosas, T.; et al. Disentangling functional trait variation and covariation in epiphytic lichens along a continent-wide latitudinal gradient. Proc. R. Soc. B Biol. Sci. 2020, 287, 20192862. [CrossRef] [PubMed]

39. Hurtado, P.; Matos, P.; Aragón, G.; Branquinho, C.; Prieto, M.; Martínez, I. How much matching there is in functional, phylogenetic and taxonomic optima of epiphytic macrolichen communities along a European climatic gradient? Sci. Total Environ. 2020, 712, 136533. [CrossRef]

40. Koch, N.M.; Matos, P.; Branquinho, C.; Pinho, P.; Lucheta, F.; de Azevedo Martins, S.M.; Vargas, V.M.F. Selecting lichen functional traits as ecological indicators of the effects of urban environment. Sci. Total Environ. 2019, 654, 705-713. [CrossRef]

41. Favero-Longo, S.E.; Matteucci, E.; Giordani, P.; Paukov, A.G.; Rajakaruna, N. Diversity and functional traits of lichens in ultramafic areas: A literature-based worldwide analysis integrated by field data at the regional scale. Ecol. Res. 2018, 33, 593-608. [CrossRef]

42. Wan, S.; Ellis, C.J. Are lichen growth form categories supported by continuous functional traits: Water-holding capacity and specific thallus mass? Edinb. J. Bot. 2020, 77, 65-76. [CrossRef]

43. Aragón, G.; Belinchón, R.; Martínez, I.; Prieto, M. A survey method for assessing the richness of epiphytic lichens using growth forms. Ecol. Indic. 2016, 62, 101-105. [CrossRef]

44. Bässler, C.; Cadotte, M.W.; Beudert, B.; Heibl, C.; Blaschke, M.; Bradtka, J.H.; Langbehn, T.; Werth, S.; Müller, J. Contrasting patterns of lichen functional diversity and species richness across an elevation gradient. Ecography 2016, 39, 689-698. [CrossRef]

45. Bokhorst, S.; Asplund, J.; Kardol, P.; Wardle, D.A. Lichen physiological traits and growth forms affect communities of associated invertebrates. Ecology 2015, 96, 2394-2407. [CrossRef] [PubMed]

46. Smith, C.W.; Aptroot, A.; Coppins, B.J.; Fletcher, A.; Gilbert, O.L.; James, R.W.; Wolseley, P.A. The Lichens of Great Britain and Ireland; British Lichen Society: London, UK, 2009.

47. Nash, T.H.; Ryan, B.D.; Gries, C.; Bungartz, F. Lichen Flora of the Greater Sonoran Desert Region.; Arizona State University: Tempe, AZ, USA, 2002; Volume 1-3.

48. Rambold, G.; Davydov, E.; Elix, J.A.; Nash III, T.H.; Scheidegger, C.; Zedda, L. LIAS Light—A Database for Rapid Identification of Lichens. Available online: http:/ / liaslight.lias.net/ (accessed on 1 March 2021).

49. Consortium of North American Lichen Herbaria. Available online: https://lichenportal.org/cnalh/ (accessed on 17 February 2021).

50. Nimis, P.L.; Martellos, S. ITALIC 6.0-the Information System on Italian Lichens. Available online: http:/ / dryades.units.it/italic (accessed on 20 January 2021).

51. Austin, M.P. Spatial prediction of species distribution: An interface between ecological theory and statistical modelling. Ecol. Model. 2002, 157, 101-118. [CrossRef]

52. Jiménez-Valverde, A.; Nakazawa, Y.; Lira-Noriega, A.; Peterson, A.T. Environmental correlation structure and ecological niche model projections. Biodivers. Inform. 2009, 6, 28-35. [CrossRef]

53. Longinotti, S.; Solhaug, K.A.; Gauslaa, Y. Hydration traits in cephalolichen members of the epiphytic old forest genus Lobaria (s. lat.). Lichenologist 2017, 49, 493-506. [CrossRef]

54. Phinney, N.H.; Solhaug, K.A.; Gauslaa, Y. Rapid resurrection of chlorolichens in humid air: Specific thallus mass drives rehydration and reactivation kinetics. Environ. Exp. Bot. 2018, 148, 184-191. [CrossRef]

55. John, E. Distribution patterns and interthalline interactions of epiphytic foliose lichens. Can. J. Bot. 2011, 70, 818-823. [CrossRef]

56. Walser, J.-C. Molecular evidence for limited dispersal of vegetative propagules in the epiphytic lichen Lobaria pulmonaria. Am. J. Bot. 2004, 91, 1273-1276. [CrossRef]

57. Ott, S.; Treiber, K.; Jahns, H.M. The development of regenerative thallus structures in lichens. Bot. J. Linn. Soc. 1993, 113, 61-76. [CrossRef]

58. Tretiach, M.; Crisafulli, P.; Pittao, E.; Rinno, S.; Roccotiello, E.; Modenesi, P. Isidia ontogeny and its effect on the $\mathrm{CO}_{2}$ gas exchanges of the epiphytic lichen Pseudevernia furfuracea (L.) Zopf. Lichenologist 2005, 37, 445-462. [CrossRef]

59. Higgins, N.F.; Connan, S.; Stengel, D.B. Factors influencing the distribution of coastal lichens Hydropunctaria maura and Wahlenbergiella mucosa. Mar. Ecol. 2015, 36, 1400-1414. [CrossRef]

60. Osyczka, P.; Rola, K.; Lenart-Boron, A.; Boron, P. High intraspecific genetic and morphological variation in the pioneer lichen Cladonia rei colonising slag dumps. Open Life Sci. 2014, 9, 579-591. [CrossRef]

61. Yahr, R.; Vilgalys, R.; DePriest, P.T. Geographic variation in algal partners of Cladonia subtenuis (Cladoniaceae) highlights the dynamic nature of a lichen symbiosis. New Phytol. 2006, 171, 847-860. [CrossRef]

62. Muggia, L.; Pérez-Ortega, S.; Kopun, T.; Zellnig, G.; Grube, M. Photobiont selectivity leads to ecological tolerance and evolutionary divergence in a polymorphic complex of lichenized fungi. Ann. Bot. 2014, 114, 463-475. [CrossRef]

63. Otálora, M.A.G.; Martínez, I.; O’Brien, H.; Molina, M.C.; Aragón, G.; Lutzoni, F. Multiple origins of high reciprocal symbiotic specificity at an intercontinental spatial scale among gelatinous lichens (Collemataceae, Lecanoromycetes). Mol. Phylogenet. Evol. 2010, 56, 1089-1095. [CrossRef]

64. Leavitt, S.D.; Kraichak, E.; Nelsen, M.P.; Altermann, S.; Divakar, P.K.; Alors, D.; Esslinger, T.L.; Crespo, A.; Lumbsch, T. Fungal specificity and selectivity for algae play a major role in determining lichen partnerships across diverse ecogeographic regions in the lichen-forming family Parmeliaceae (Ascomycota). Mol. Ecol. 2015, 24, 3779-3797. [CrossRef] 
65. Magain, N.; Miadlikowska, J.; Goffinet, B.; Sérusiaux, E.; Lutzoni, F. Macroevolution of specificity in cyanolichens of the genus Peltigera Section Polydactylon (Lecanoromycetes, Ascomycota). Syst. Biol. 2017, 66, 74-99. [CrossRef]

66. Trenbirth, H.E. Lichenometry. In Geomorphological Techniques; British Society for Geomorphology: London, UK, $2010 ;$ pp. 1-12.

67. Oliveira, M.A.; Llop, E.; Andrade, C.; Branquinho, C.; Goble, R.; Queiroz, S.; Freitas, M.C.; Pinho, P. Estimating the age and mechanism of boulder transport related with extreme waves using lichenometry. Prog. Phys. Geogr. Earth Environ. 2020, 44, 870-897. [CrossRef]

68. Roca Valiente, B.; Hawksworth, D.; Pérez-Ortega, S.; Sancho, L.; Crespo, A. Type studies in the Rhizocarpon geographicum group (Rhizocarpaceae, lichenized Ascomycota). Lichenologist 2016, 48, 97-110. [CrossRef]

69. Armstrong, R.A. Lichenometric dating (Lichenometry) and the biology of the lichen genus Rhizocarpon: Challenges and future directions. Geogr. Ann. Ser. Phys. Geogr. 2016, 98, 183-206. [CrossRef]

70. Merinero, S.; Martínez, I.; Rubio-Salcedo, M.; Gauslaa, Y. Epiphytic lichen growth in Mediterranean forests: Effects of proximity to the ground and reproductive stage. Basic Appl. Ecol. 2015, 16, 220-230. [CrossRef]

71. Merinero, S.; Aragón, G.; Martínez, I. Intraspecific life history variation in contrasting habitats: Insights from an obligate symbiotic organism. Am. J. Bot. 2017, 104, 1099-1107. [CrossRef]

72. Shivarov, V.V.; Denchev, C.M.; Thüs, H. Ecology and distribution of Dermatocarpon (Verrucariaceae, Ascomycota) in the catchment areas of two Bulgarian rivers. Lichenologist 2018, 50, 679-690. [CrossRef]

73. Coyle, J.R. Intraspecific variation in epiphyte functional traits reveals limited effects of microclimate on community assembly in temperate deciduous oak canopies. Oikos 2017, 126, 111-120. [CrossRef]

74. Roos, R.E.; Zuijlen, K.; Birkemoe, T.; Klanderud, K.; Lang, S.I.; Bokhorst, S.; Wardle, D.A.; Asplund, J. Contrasting drivers of community-level trait variation for vascular plants, lichens and bryophytes across an elevational gradient. Funct. Ecol. 2019, 33, 2430-2446. [CrossRef]

75. Asplund, J.; Wardle, D.A. How lichens impact on terrestrial community and ecosystem properties: How lichens impact on communities and ecosystems. Biol. Rev. 2017, 92, 1720-1738. [CrossRef]

76. Zedda, L.; Rambold, G. The diversity of lichenised fungi: Ecosystem functions and ecosystem services. In Recent Advances in Lichenology: Modern Methods and Approaches in Lichen Systematics and Culture Techniques, Volume 2; Upreti, D.K., Divakar, P.K., Shukla, V., Bajpai, R., Eds.; Springer India: New Delhi, India, 2015; pp. 121-145. ISBN 978-81-322-2235-4.

77. Haines-Young, R.; Potschin, M. Common International Classification of Ecosystem Services (CICES) V5. 1 Guidance on the Application of the Revised Structure, UK, 2017; The Paddocks, Chestnut Lane: Nottingham, UK, 2020.

78. Concostrina-Zubiri, L.; Molla, I.; Velizarova, E.; Branquinho, C. Grazing or not grazing: Implications for ecosystem services provided by biocrusts in Mediterranean cork oak woodlands. Land Degrad. Dev. 2017, 28, 1345-1353. [CrossRef]

79. Van Zuijlen, K.; Roos, R.E.; Klanderud, K.; Lang, S.I.; Asplund, J. Mat-forming lichens affect microclimate and litter decomposition by different mechanisms. Fungal Ecol. 2020, 44, 100905. [CrossRef]

80. Nystuen, K.O.; Sundsdal, K.; Opedal, Ø.H.; Holien, H.; Strimbeck, G.R.; Graae, B.J. Lichens facilitate seedling recruitment in alpine heath. J. Veg. Sci. 2019, 30, 868-880. [CrossRef]

81. Soudzilovskaia, N.A.; van Bodegom, P.M.; Cornelissen, J.H.C. Dominant bryophyte control over high-latitude soil temperature fluctuations predicted by heat transfer traits, field moisture regime and laws of thermal insulation. Funct. Ecol. 2013, 27, 1442-1454. [CrossRef]

82. Kershaw, K.A. Studies on lichen-dominated systems. XII. The ecological significance of thallus color. Can. J. Bot. 2011, 53, 660-667. [CrossRef]

83. Gauslaa, Y. Heat resistance and energy budget in different Scandinavian plants. Ecography 1984, 7, 5-6. [CrossRef]

84. Aartsma, P.; Asplund, J.; Odland, A.; Reinhardt, S.; Renssen, H. Surface albedo of alpine lichen heaths and shrub vegetation. Arct. Antarct. Alp. Res. 2020, 52, 312-322. [CrossRef]

85. Porada, P.; Van Stan, J.T.; Kleidon, A. Significant contribution of non-vascular vegetation to global rainfall interception. Nat. Geosci. 2018, 11, 563-567. [CrossRef]

86. Van Stan, J.T.; Pypker, T.G. A review and evaluation of forest canopy epiphyte roles in the partitioning and chemical alteration of precipitation. Sci. Total Environ. 2015, 536, 813-824. [CrossRef]

87. Pypker, T.G.; Unsworth, M.H.; Bond, B.J. The role of epiphytes in rainfall interception by forests in the Pacific Northwest. I. Laboratory measurements of water storage. Can. J. For. Res. 2006, 36, 809-818. [CrossRef]

88. Stanton, D.E.; Chávez, J.H.; Villegas, L.; Villasante, F.; Armesto, J.; Hedin, L.O.; Horn, H. Epiphytes improve host plant water use by microenvironment modification. Funct. Ecol. 2014, 28, 1274-1283. [CrossRef]

89. Solhaug, K.A.; Lind, M.; Nybakken, L.; Gauslaa, Y. Possible functional roles of cortical depsides and medullary depsidones in the foliose lichen Hypogymnia physodes. Flora 2009, 204, 40-48. [CrossRef]

90. Gauslaa, Y.; Coxson, D. Interspecific and intraspecific variations in water storage in epiphytic old forest foliose lichens. Botany 2011, 89, 787-798. [CrossRef]

91. Knops, J.M.H.; Nash, T.H.I.; Boucher, V.L.; Schlesinger, W.H. Mineral cycling and epiphytic lichens: Implications at the ecosystem level. Lichenologist 1991, 23, 309-321. [CrossRef]

92. Knops, J.M.H.; Nash, T.H.; Schlesinger, W.H. The influence of epiphytic lichens on the nutrient cycling of an oak woodland. Ecol. Monogr. 1996, 66, 159-180. [CrossRef] 
93. Porada, P.; Weber, B.; Elbert, W.; Pöschl, U.; Kleidon, A. Estimating impacts of lichens and bryophytes on global biogeochemical cycles. Glob. Biogeochem. Cycles 2014, 28, 71-85. [CrossRef]

94. Adamo, P.; Violante, P. Weathering of rocks and neogenesis of minerals associated with lichen activity. Appl. Clay Sci. 2000, 16, 229-256. [CrossRef]

95. Chen, J.; Blume, H.-P.; Beyer, L. Weathering of rocks induced by lichen colonization-A review. CATENA 2000, 39, 121-146. [CrossRef]

96. Carter, N.E.A.; Viles, H.A. Lichen hotspots: Raised rock temperatures beneath Verrucaria nigrescens on limestone. Geomorphology 2004, 62, 1-16. [CrossRef]

97. Favero-Longo, S.E.; Viles, H.A. A review of the nature, role and control of lithobionts on stone cultural heritage: Weighing-up and managing biodeterioration and bioprotection. World J. Microbiol. Biotechnol. 2020, 36, 100. [CrossRef]

98. Van Zuijlen, K.; Roos, R.E.; Klanderud, K.; Lang, S.I.; Wardle, D.A.; Asplund, J. Decomposability of lichens and bryophytes from across an elevational gradient under standardized conditions. Oikos 2020, 129, 1358-1368. [CrossRef]

99. Benesperi, R.; Tretiach, M. Differential land snail damage to selected species of the lichen genus Peltigera. Biochem. Syst. Ecol. 2004, 32, 127-138. [CrossRef]

100. Gauslaa, Y. Lichen palatability depends on investments in herbivore defence. Oecologia 2005, 143, 94-105. [CrossRef]

101. Nimis, P.L.; Skert, N. Lichen chemistry and selective grazing by the coleopteran Lasioderma serricorne. Environ. Exp. Bot. 2006, 55, 175-182. [CrossRef]

102. Asplund, J.; Bokhorst, S.; Kardol, P.; Wardle, D.A. Removal of secondary compounds increases invertebrate abundance in lichens. Fungal Ecol. 2015, 18, 18-25. [CrossRef]

103. Geiser, L.H.; Nelson, P.R.; Jovan, S.E.; Root, H.T.; Clark, C.M. Assessing ecological risks from atmospheric deposition of nitrogen and sulfur to US forests using epiphytic macrolichens. Diversity 2019, 11, 87. [CrossRef]

104. Ladrón de Guevara, M.; Gozalo, B.; Raggio, J.; Lafuente, A.; Prieto, M.; Maestre, F.T. Warming reduces the cover, richness and evenness of lichen-dominated biocrusts but promotes moss growth: Insights from an 8 yr experiment. New Phytol. 2018, 220, 811-823. [CrossRef] [PubMed]

105. Escudero, A.; Martínez, I.; de la Cruz, A.; Otálora, M.A.G.; Maestre, F.T. Soil lichens have species-specific effects on the seedling emergence of three gypsophile plant species. J. Arid Environ. 2007, 70, 18-28. [CrossRef]

106. Eldridge, D.J.; Rosentreter, R. Morphological groups: A framework for monitoring microphytic crusts in arid landscapes. J. Arid Environ. 1999, 41, 11-25. [CrossRef]

107. Chamizo, S.; Canton, Y.; Afana, A.; Lazaro, R.; Domingo, F.; Sole-Benet, A. How development and disturbance of biological soil crust do affect runoff and erosion in drylands? In Advances in Studies on Desertification; Romero-Díaz, A., Belmonte, F., Alonso, F., López Bermúdez, F., Eds.; Servicio Publicaciones Universidad de Murcia EDITUM: Murcia, Spain, 2009; pp. $203-206$.

108. Southwood, T.R.E. Habitat, the templet for ecological strategies? J. Anim. Ecol. 1977, 46, 337-365. [CrossRef]

109. Southwood, T.R.E. Tactics, strategies and templets. Oikos 1988, 52, 3-18. [CrossRef]

110. Gauslaa, Y.; Solhaug, K.A. The significance of thallus size for the water economy of the cyanobacterial old-forest lichen Degelia plumbea. Oecologia 1998, 116, 76-84. [CrossRef]

111. Went, F.W. Soziologie der Epiphyten eines tropischen Regenwaldes. Ann. Jard. Bot. Buitenzorg 1940, 50, 1-98.

112. Zotz, G.; Winkler, U. Aerial roots of epiphytic orchids: The velamen radicum and its role in water and nutrient uptake. Oecologia 2013, 171, 733-741. [CrossRef]

113. Grube, M.; Hawksworth, D.L. Trouble with lichen: The re-evaluation and re-interpretation of thallus form and fruit body types in the molecular era. Mycol. Res. 2007, 111, 1116-1132. [CrossRef]

114. Muggia, L.; Nelson, P.; Wheeler, T.; Yakovchenko, L.S.; Tønsberg, T.; Spribille, T. Convergent evolution of a symbiotic duet: The case of the lichen genus Polychidium (Peltigerales, Ascomycota). Am. J. Bot. 2011, 98, 1647-1656. [CrossRef]

115. Aptroot, A.; Schumm, F. The genus Melanophloea, an example of convergent evolution towards polyspory. Lichenologist 2012, 44, 501-509. [CrossRef]

116. Prieto, M.; Baloch, E.; Tehler, A.; Wedin, M. Mazaedium evolution in the Ascomycota (Fungi) and the classification of mazaediate groups of formerly unclear relationship. Cladistics 2013, 29, 296-308. [CrossRef]

117. Miadlikowska, J.; Kauff, F.; Hofstetter, V.; Fraker, E.; Grube, M.; Hafellner, J.; Reeb, V.; Hodkinson, B.P.; Kukwa, M.; Lücking, R.; et al. New insights into classification and evolution of the Lecanoromycetes (Pezizomycotina, Ascomycota) from phylogenetic analyses of three ribosomal RNA- and two protein-coding genes. Mycologia 2006, 98, 1088-1103. [CrossRef] [PubMed]

118. Hodkinson, B.P.; Gottel, N.R.; Schadt, C.W.; Lutzoni, F. Photoautotrophic symbiont and geography are major factors affecting highly structured and diverse bacterial communities in the lichen microbiome. Environ. Microbiol. 2012, 14, 147-161. [CrossRef] [PubMed]

119. McCune, B. Gradients in epiphyte biomass in three Pseudotsuga-Tsuga forests of different ages in Western Oregon and Washington. Bryologist 1993, 96, 405-411. [CrossRef]

120. McCune, B.; Amsberry, K.A.; Camacho, F.J.; Clery, S.; Cole, C.; Emerson, C.; Felder, G.; French, P.; Greene, D.; Harris, R. Vertical profile of epiphytes in a Pacific Northwest old-growth forest. Northwest. Sci. 1997, 71, 145-152.

121. Sillett, S.C.; Rambo, T.R. Vertical distribution of dominant epiphytes in Douglas-fir forests of the central Oregon Cascades. Northwest. Sci. 2000, 74, 44-49. 
122. Lange, O.L.; Green, T.G.A.; Ziegler, H. Water status related photosynthesis and carbon isotope discrimination in species of the lichen genus Pseudocyphellaria with green or blue-green photobionts and in photosymbiodemes. Oecologia 1988, 75, 494-501. [CrossRef]

123. Green, T.G.A.; Büdel, B.; Meyer, A.; Zellner, H.; Lange, O.L. Temperate rainforest lichens in New Zealand: Light response of photosynthesis. N. Z. J. Bot. 1997, 35, 493-504. [CrossRef]

124. Färber, L.; Solhaug, K.A.; Esseen, P.-A.; Bilger, W.; Gauslaa, Y. Sunscreening fungal pigments influence the vertical gradient of pendulous lichens in boreal forest canopies. Ecology 2014, 95, 1464-1471. [CrossRef]

125. Ellis, C.J.; Ellis, S.C. Signatures of autogenic epiphyte succession for an aspen chronosequence. J. Veg. Sci. 2013, $24,688-701$. [CrossRef]

126. Nascimbene, J.; Mayrhofer, H.; Dainese, M.; Bilovitz, P.O. Assembly patterns of soil-dwelling lichens after glacier retreat in the European Alps. J. Biogeogr. 2017, 44, 1393-1404. [CrossRef]

127. Ellis, C.J.; Coppins, B.J. Reproductive strategy and the compositional dynamics of crustose lichen communities on aspen (Populus tremula L.) in Scotland. Lichenologist 2007, 39, 377-391. [CrossRef]

128. MacArthur, R.H.; Wilson, E.O. The Theory of Island Biogeography; Princeton University Press: Princeton, NJ, USA, 2001.

129. Pianka, E.R. On r-and K-selection. Am. Nat. 1970, 104, 592-597. [CrossRef]

130. Hauck, M.; Jürgens, S.-R.; Brinkmann, M.; Herminghaus, S. Surface hydrophobicity causes $\mathrm{SO}_{2}$ tolerance in lichens. Ann. Bot. 2008, 101, 531-539. [CrossRef] [PubMed]

131. Hauck, M.; Wirth, V. Preference of lichens for shady habitats is correlated with intolerance to high nitrogen levels. Lichenologist 2010, 42, 475. [CrossRef]

132. Grime, J.P. Vegetation classification by reference to strategies. Nature 1974, 250, 26-31. [CrossRef]

133. Grime, J.P. Evidence for the existence of three primary strategies in plants and its relevance to ecological and evolutionary theory. Am. Nat. 1977, 111, 1169-1194. [CrossRef]

134. Lutzoni, F.; Pagel, M.; Reeb, V. Major fungal lineages are derived from lichen symbiotic ancestors. Nature 2001, 411, 937-940. [CrossRef] [PubMed]

135. Rogers, R.W. Ecological strategies of lichens. Lichenologist 1990, 22, 149-162. [CrossRef]

136. Di Nuzzo, L.; Vallese, C.; Benesperi, R.; Giordani, P.; Chiarucci, A.; Di Cecco, V.; Di Martino, L.; Di Musciano, M.; Gheza, G.; Lelli, C.; et al. Contrasting multitaxon responses to climate change in Mediterranean mountains. Sci. Rep. 2021, 11, 4438. [CrossRef]

137. De Bello, F.; Berg, M.P.; Dias, A.T.; Diniz-Filho, J.A.F.; Götzenberger, L.; Hortal, J.; Ladle, R.J.; Lepš, J. On the need for phylogenetic' corrections' in functional trait-based approaches. Folia Geobot. 2015, 50, 349-357. [CrossRef]

138. Li, D.; Ives, A.R. The statistical need to include phylogeny in trait-based analyses of community composition. Methods Ecol. Evol. 2017, 8, 1192-1199. [CrossRef]

139. Li, D.; Ives, A.R.; Waller, D.M. Can functional traits account for phylogenetic signal in community composition? New Phytol. 2017, 214, 607-618. [CrossRef]

140. Horner-Devine, M.C.; Bohannan, B.J.M. Phylogenetic clustering and overdispersion in bacterial communities. Ecology 2006, 87, S100-S108. [CrossRef]

141. Goberna, M.; Navarro-Cano, J.A.; Valiente-Banuet, A.; García, C.; Verdú, M. Abiotic stress tolerance and competition-related traits underlie phylogenetic clustering in soil bacterial communities. Ecol. Lett. 2014, 17, 1191-1201. [CrossRef]

142. Ives, A.R.; Helmus, M.R. Generalized linear mixed models for phylogenetic analyses of community structure. Ecol. Monogr. 2011, 81, 511-525. [CrossRef]

143. Ives, A.R. $\mathrm{R}^{2}$ s for correlated data: Phylogenetic models, LMMs, and GLMMs. Syst. Biol. 2019, 68, 234-251. [CrossRef] [PubMed]

144. Prieto, M.; Martínez, I.; Aragón, G.; Verdú, M. Phylogenetic and functional structure of lichen communities under contrasting environmental conditions. J. Veg. Sci. 2017, 28, 871-881. [CrossRef]

145. McGill, B.J. Exploring predictions of abundance from body mass using hierarchical comparative approaches. Am. Nat. 2008, 172, 88-101. [CrossRef]

146. Ellis, C.J.; Eaton, S. Microclimates hold the key to spatial forest planning under climate change: Cyanolichens in temperate rainforest. Glob. Change Biol. 2021, 1-12. [CrossRef]

147. Ellis, C.; Eaton, S. Climate change refugia: Landscape, stand and tree-scale microclimates in epiphyte community composition. Lichenologist 2021, 53, 135-148. [CrossRef]

148. Levin, S.A. The problem of pattern and scale in ecology: The Robert, H. MacArthur award lecture. Ecology 1992, 73, 1943-1967. [CrossRef]

149. Odum, E.P.; Barrett, G.W. Fundamentals of Ecology; Saunders: Philadelphia, PA, USA, 1971; Volume 3.

150. Pardow, A.; Hartard, B.; Lakatos, M. Morphological, photosynthetic and water relations traits underpin the contrasting success of two tropical lichen groups at the interior and edge of forest fragments. AoB Plants 2010, 2010. [CrossRef] [PubMed]

151. Dawkins, R. The Extended Phenotype; Oxford University Press: Oxford, UK, 1982.

152. Cruz de Carvalho, R.; Varela, Z.; do Paço, T.A.; Branquinho, C. Selecting potential moss species for green roofs in the Mediterranean Basin. Urban. Sci. 2019, 3, 57. [CrossRef]

153. Cruz de Carvalho, R.; Branquinho, C.; Marques da Silva, J. Physiological consequences of desiccation in the aquatic bryophyte Fontinalis antipyretica. Planta 2011, 234, 195-205. [CrossRef] [PubMed] 
154. Branquinho, C.; Serrano, H.C.; Nunes, A.; Pinho, P.; Matos, P. Essential biodiversity change indicators for evaluating the effects of Anthropocene in ecosystems at a global scale. In From Assessing to Conserving Biodiversity; Casetta, E., Marques da Silva, J., Vecchi, D., Eds.; Springer: Cham, Germany, 2019; pp. 137-163.

155. Matos, P.; Geiser, L.; Hardman, A.; Glavich, D.; Pinho, P.; Nunes, A.; Soares, A.M.V.M.; Branquinho, C. Tracking global change using lichen diversity: Towards a global-scale ecological indicator. Methods Ecol. Evol. 2017, 8, 788-798. [CrossRef]

156. Giordani, P.; Incerti, G.; Rizzi, G.; Rellini, I.; Nimis, P.L.; Modenesi, P. Functional traits of cryptogams in Mediterranean ecosystems are driven by water, light and substrate interactions. J. Veg. Sci. 2014, 25, 778-792. [CrossRef]

157. Porada, P.; Weber, B.; Elbert, W.; Pöschl, U.; Kleidon, A. Estimating global carbon uptake by lichens and bryophytes with a process-based model. Biogeosciences 2013, 10, 6989-7033. [CrossRef]

158. Pinho, P.; Augusto, S.; Máguas, C.; Pereira, M.J.; Soares, A.; Branquinho, C. Impact of neighbourhood land-cover in epiphytic lichen diversity: Analysis of multiple factors working at different spatial scales. Environ. Pollut. 2008, 151, 414-422. [CrossRef]

159. Hurtado, P.; Prieto, M.; Aragón, G.; Escudero, A.; Martínez, I. Critical predictors of functional, phylogenetic and taxonomic diversity are geographically structured in lichen epiphytic communities. J. Ecol. 2019, 107, 2303-2316. [CrossRef]

160. Nascimbene, J.; Benesperi, R.; Brunialti, G.; Catalano, I.; Vedove, M.D.; Grillo, M.; Isocrono, D.; Matteucci, E.; Potenza, G.; Puntillo, D.; et al. Patterns and drivers of $\beta$-diversity and similarity of Lobaria pulmonaria communities in Italian forests. J. Ecol. 2013, 101, 493-505. [CrossRef]

161. Merinero, S.; Rubio-Salcedo, M.; Aragón, G.; Martínez, I. Environmental factors that drive the distribution and abundance of a threatened cyanolichen in Southern Europe: A multi-scale approach. Am. J. Bot. 2014, 101, 1876-1885. [CrossRef] [PubMed]

162. Werth, S.; Cheenacharoen, S.; Scheidegger, C. Propagule size is not a good predictor for regional population subdivision or fine-scale spatial structure in lichenized fungi. Fungal Biol. 2014, 118, 126-138. [CrossRef]

163. Rubio-Salcedo, M.; Merinero, S.; Martínez, I. Tree species and microhabitat influence the population structure of the epiphytic lichen Lobaria pulmonaria. Fungal Ecol. 2015, 18, 1-9. [CrossRef]

164. Benesperi, R.; Nascimbene, J.; Lazzaro, L.; Bianchi, E.; Tepsich, A.; Longinotti, S.; Giordani, P. Successful conservation of the endangered forest lichen Lobaria pulmonaria requires knowledge of fine-scale population structure. Fungal Ecol. 2018, 33, 65-71. [CrossRef]

165. Príncipe, A.; Matos, P.; Sarris, D.; Gaiola, G.; do Rosário, L.; Correia, O.; Branquinho, C. In Mediterranean drylands microclimate affects more tree seedlings than adult trees. Ecol. Indic. 2019, 106, 105476. [CrossRef]

166. Pinho, P.; Dias, T.; Cruz, C.; Tang, Y.S.; Sutton, M.A.; Martins-Loução, M.-A.; Máguas, C.; Branquinho, C. Using lichen functional diversity to assess the effects of atmospheric ammonia in Mediterranean woodlands. J. Appl. Ecol. 2011, 48, 1107-1116. [CrossRef]

167. Pinho, P.; Theobald, M.R.; Dias, T.; Tang, Y.S.; Cruz, C.; Martins-Loução, M.A.; Máguas, C.; Sutton, M.; Branquinho, C. Critical loads of nitrogen deposition and critical levels of atmospheric ammonia for semi-natural Mediterranean evergreen woodlands. Biogeosciences 2012, 9, 1205-1215. [CrossRef]

168. Bowker, M.A.; Belnap, J.; Davidson, D.W.; Goldstein, H. Correlates of biological soil crust abundance across a continuum of spatial scales: Support for a hierarchical conceptual model. J. Appl. Ecol. 2006, 43, 152-163. [CrossRef]

169. Giordani, P.; Rizzi, G.; Caselli, A.; Modenesi, P.; Malaspina, P.; Mariotti, M.G. Fire affects the functional diversity of epilithic lichen communities. Fungal Ecol. 2016, 20, 49-55. [CrossRef]

170. Concostrina-Zubiri, L.; Huber-Sannwald, E.; Martínez, I.; Flores Flores, J.L.; Escudero, A. Biological soil crusts greatly contribute to small-scale soil heterogeneity along a grazing gradient. Soil Biol. Biochem. 2013, 64, 28-36. [CrossRef]

171. Concostrina-Zubiri, L.; Pescador, D.S.; Martínez, I.; Escudero, A. Climate and small scale factors determine functional diversity shifts of biological soil crusts in Iberian drylands. Biodivers. Conserv. 2014, 23, 1757-1770. [CrossRef]

172. Van Herk, C.M.; Aptroot, A.; van Dobben, H.F. Long-term monitoring in the Netherlands suggests that lichens respond to global warming. Lichenologist 2002, 34, 141-154. [CrossRef]

173. Aptroot, A.; van Herk, C.M. Further evidence of the effects of global warming on lichens, particularly those with Trentepohlia phycobionts. Environ. Pollut. 2007, 146, 293-298. [CrossRef]

174. Matos, P. Development of Ecological Indicators of Climate Change Based on Lichen Functional Diversity. PhD Thesis, Universidade de Aveiro (Portugal), Averio, Portugal, 2016.

175. Saniewski, M.; Wietrzyk-Pełka, P.; Zalewska, T.; Osyczka, P.; Wegrzyn, M.H. Impact of distance from the glacier on the content of ${ }^{137} \mathrm{Cs}$ and ${ }^{90} \mathrm{Sr}$ in the lichen Cetrariella delisei. Chemosphere 2020, 259, 127433. [CrossRef] [PubMed]

176. Marini, L.; Nascimbene, J.; Nimis, P.L. Large-scale patterns of epiphytic lichen species richness: Photobiont-dependent response to climate and forest structure. Sci. Total Environ. 2011, 409, 4381-4386. [CrossRef]

177. Giordani, P. Assessing the effects of forest management on epiphytic lichens in coppiced forests using different indicators. Plant. Biosyst.-Int. J. Deal. Asp. Plant. Biol. 2012, 1-10. [CrossRef]

178. Giordani, P.; Malaspina, P.; Benesperi, R.; Incerti, G.; Nascimbene, J. Functional over-redundancy and vulnerability of lichen communities decouple across spatial scales and environmental severity. Sci. Total Environ. 2019, 666, 22-30. [CrossRef]

179. Reutimann, P.; Scheidegger, C. Importance of lichen secondary products in food choice of two oribatid mites (Acari) in an alpine meadow ecosystem. J. Chem. Ecol. 1987, 13, 363-369. [CrossRef] [PubMed]

180. Hesbacher, S.; Giez, I.; Embacher, G.; Fiedler, K.; Max, W.; Trawöger, A.; Türk, R.; Lange, O.L.; Proksch, P. Sequestration of lichen compounds by lichen-feeding members of the Arctiidae (Lepidoptera). J. Chem. Ecol. 1995, 21, 2079-2089. [CrossRef] [PubMed] 
181. Boch, S.; Fischer, M.; Prati, D. To eat or not to eat-relationship of lichen herbivory by snails with secondary compounds and field frequency of lichens. J. Plant. Ecol. 2015, 8, 642-650. [CrossRef]

182. Lücking, R.; Bernecker-Lücking, A. Lichen feeders and lichenicolous fungi: Do they affect dispersal and diversity in tropical foliicolous lichen communities. Ecotropica 2000, 6, 23-41.

183. Asplund, J.; Gauslaa, Y. Mollusc grazing limits growth and early development of the old forest lichen Lobaria pulmonaria in broadleaved deciduous forests. Oecologia 2008, 155, 93-99. [CrossRef] [PubMed]

184. Vatne, S.; Solhøy, T.; Asplund, J.; Gauslaa, Y. Grazing damage in the old forest lichen Lobaria pulmonaria increases with gastropod abundance in deciduous forests. Lichenologist 2010, 42, 615-619. [CrossRef]

185. Boch, S.; Prati, D.; Werth, S.; Rüetschi, J.; Fischer, M. Lichen endozoochory by snails. PLoS ONE 2011, 6, 18770. [CrossRef]

186. Asplund, J.; Larsson, P.; Vatne, S.; Gauslaa, Y. Gastropod grazing shapes the vertical distribution of epiphytic lichens in forest canopies. J. Ecol. 2010, 98, 218-225. [CrossRef]

187. Prentice, I.C. Non-metric ordination methods in ecology. J. Ecol. 1977, 65, 85-94. [CrossRef]

188. Murtagh, F.; Legendre, P. Ward's hierarchical agglomerative clustering method: Which algorithms implement Ward's criterion? J. Classif. 2014, 31, 274-295. [CrossRef]

189. Miller, P.J.; Lubke, G.H.; McArtor, D.B.; Bergeman, C.S. Finding structure in data using multivariate tree boosting. Psychol. Methods 2016, 21, 583-602. [CrossRef] [PubMed]

190. Miller, P.J. Boosted Decision Trees for Multivariate, Hierarchically Clustered, and Longitudinal Data; University of Notre Dame: Notre Dame, IN, USA, 2017.

191. Nelson, P.R.; McCune, B.; Swanson, D.K. Lichen traits and species as indicators of vegetation and environment. Bryologist 2015, 118, 252. [CrossRef]

192. Nelson, P.R.; McCune, B.; Roland, C.; Stehn, S. Non-parametric methods reveal non-linear functional trait variation of lichens along environmental and fire age gradients. J. Veg. Sci. 2015, 26, 848-865. [CrossRef]

193. Dray, S.; Legendre, P. Testing the species traits-environment relationships: The fourth-corner problem revisited. Ecology 2008, 89 , 3400-3412. [CrossRef]

194. Dray, S.; Choler, P.; Dolédec, S.; Peres-Neto, P.R.; Thuiller, W.; Pavoine, S.; ter Braak, C.J.F. Combining the fourth-corner and the RLQ methods for assessing trait responses to environmental variation. Ecology 2014, 95, 14-21. [CrossRef] [PubMed]

195. Ter Braak, C.J.F. New robust weighted averaging- and model-based methods for assessing trait-environment relationships. Methods Ecol. Evol. 2019, 10, 1962-1971. [CrossRef]

196. Braga, J.; Ter Braak, C.J.F.; Thuiller, W.; Dray, S. Integrating spatial and phylogenetic information in the fourth-corner analysis to test trait-environment relationships. Ecology 2018, 99, 2667-2674. [CrossRef]

197. Eriksson, A.; Gauslaa, Y.; Palmqvist, K.; Ekström, M.; Esseen, P.-A. Morphology drives water storage traits in the globally widespread lichen genus Usnea. Fungal Ecol. 2018, 35, 51-61. [CrossRef]

198. Casano, L.M.; del Campo, E.M.; García-Breijo, F.J.; Reig-Armiñana, J.; Gasulla, F.; del Hoyo, A.; Guéra, A.; Barreno, E. Two Trebouxia algae with different physiological performances are ever-present in lichen thalli of Ramalina farinacea. Coexistence versus Competition? Environ. Microbiol. 2011, 13, 806-818. [CrossRef]

199. Eaton, S.; Zúñiga, C.; Czyzewski, J.; Ellis, C.; Genney, D.R.; Haydon, D.; Mirzai, N.; Yahr, R. A method for the direct detection of airborne dispersal in lichens. Mol. Ecol. Resour. 2018, 18, 240-250. [CrossRef]

200. Bianchi, E.; Benesperi, R.; Colzi, I.; Coppi, A.; Lazzaro, L.; Paoli, L.; Papini, A.; Pignattelli, S.; Tani, C.; Vignolini, P.; et al. The multi-purpose role of hairiness in the lichens of coastal environments: Insights from Seirophora villosa (Ach.) Frödén. Plant. Physiol. Biochem. 2019, 141, 398-406. [CrossRef] [PubMed]

201. Prieto, M.; Martínez, I.; Aragón, G.; Gueidan, C.; Lutzoni, F. Molecular phylogeny of Heteroplacidium, Placidium, and related catapyrenioid genera (Verrucariaceae, lichen-forming Ascomycota). Am. J. Bot. 2012, 99, 23-35. [CrossRef]

202. Thüs, H. Taxonomie, Verbreitung und Ökologie silicoler-Süßwasserflechten im außeralpinen Mitteleuropa. Mycotaxon 2003, 87, 66.

203. Esseen, P.-A.; Olsson, T.; Coxson, D.; Gauslaa, Y. Morphology influences water storage in hair lichens from boreal forest canopies. Fungal Ecol. 2015, 18, 26-35. [CrossRef]

204. Bianchi, E.; Paoli, L.; Colzi, I.; Coppi, A.; Gonnelli, C.; Lazzaro, L.; Loppi, S.; Papini, A.; Vannini, A.; Benesperi, R. High-light stress in wet and dry thalli of the endangered Mediterranean lichen Seirophora villosa (Ach.) Frödén: Does size matter? Mycol. Prog. 2019, 18, 463-470. [CrossRef]

205. Gauslaa, Y.; Solhaug, K.A. Photoinhibition in lichens depends on cortical characteristics and hydration. Lichenologist 2004, 36, 133-143. [CrossRef]

206. Olivier-Jimenez, D.; Chollet-Krugler, M.; Rondeau, D.; Beniddir, M.A.; Ferron, S.; Delhaye, T.; Allard, P.-M.; Wolfender, J.-L.; Sipman, H.J.M.; Lücking, R.; et al. A database of high-resolution MS/MS spectra for lichen metabolites. Sci. Data $2019,6,294$. [CrossRef] [PubMed]

207. Nguyen, T.T.T.; Chollet-Krugler, M.; Dévéhat, F.L.-L.; Rouaud, I.; Boustie, J. Mycosporine-like compounds in chlorolichens: Isolation from Dermatocarpon luridum and Dermatocarpon miniatum, and their photoprotective properties. Planta Medica Lett. 2015, 2, 1-5. [CrossRef]

208. Lang, S.I.; Cornelissen, J.H.C.; Klahn, T.; Logtestijn, R.S.P.V.; Broekman, R.; Schweikert, W.; Aerts, R. An experimental comparison of chemical traits and litter decomposition rates in a diverse range of subarctic bryophyte, lichen and vascular plant species. $J$. Ecol. 2009, 97, 886-900. [CrossRef] 
209. Diaz, S.; Symstad, A.J.; Stuart Chapin, F.; Wardle, D.A.; Huenneke, L.F. Functional diversity revealed by removal experiments. Trends Ecol. Evol. 2003, 18, 140-146. [CrossRef]

210. Fanin, N.; Kardol, P.; Farrell, M.; Kempel, A.; Ciobanu, M.; Nilsson, M.; Gundale, M.J.; Wardle, D.A. Effects of plant functional group removal on structure and function of soil communities across contrasting ecosystems. Ecol. Lett. 2019, 22, 1095-1103. [CrossRef]

211. Wardle, D.A.; Gundale, M.J.; Kardol, P.; Nilsson, M.; Fanin, N. Impact of plant functional group and species removals on soil and plant nitrogen and phosphorus across a retrogressive chronosequence. J. Ecol. 2020, 108, 561-573. [CrossRef]

212. Mensens, C.; De Laender, F.; Janssen, C.R.; Sabbe, K.; De Troch, M. Different response-effect trait relationships underlie contrasting responses to two chemical stressors. J. Ecol. 2017, 105, 1598-1609. [CrossRef]

213. Zambare, V.P.; Christopher, L.P. Biopharmaceutical potential of lichens. Pharm. Biol. 2012, 50, 778-798. [CrossRef]

214. Devkota, S.; Chaudhary, R.P.; Werth, S.; Scheidegger, C. Indigenous knowledge and use of lichens by the lichenophilic communities of the Nepal Himalaya. J. Ethnobiol. Ethnomedicine 2017, 13, 15. [CrossRef] 